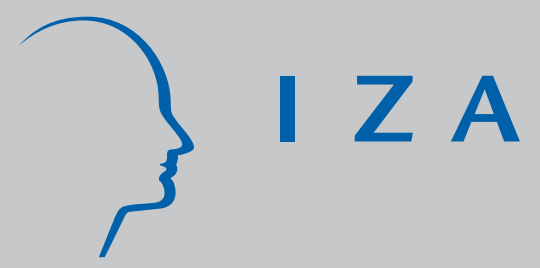

IZA DP No. 373

Does the Statutory Overtime Premium Discourage Long Workweeks?

Stephen J . Trejo

October 2001 


\title{
Does the Statutory Overtime Premium Discourage Long Workweeks?
}

\author{
Stephen J. Trejo \\ Department of Economics, University of Texas \\ and IZA, Bonn
}

Discussion Paper No. 373

October 2001

\author{
IZA \\ P.O. Box 7240 \\ D-53072 Bonn \\ Germany \\ Tel.: +49-228-3894-0 \\ Fax: +49-228-3894-210 \\ Email: iza@iza.org
}

This Discussion Paper is issued within the framework of IZA's research area Mobility and Flexibility of Labor Markets. Any opinions expressed here are those of the author(s) and not those of the institute. Research disseminated by IZA may include views on policy, but the institute itself takes no institutional policy positions.

The Institute for the Study of Labor (IZA) in Bonn is a local and virtual international research center and a place of communication between science, politics and business. IZA is an independent, nonprofit limited liability company (Gesellschaft mit beschränkter Haftung) supported by the Deutsche Post AG. The center is associated with the University of Bonn and offers a stimulating research environment through its research networks, research support, and visitors and doctoral programs. IZA engages in (i) original and internationally competitive research in all fields of labor economics, (ii) development of policy concepts, and (iii) dissemination of research results and concepts to the interested public. The current research program deals with (1) mobility and flexibility of labor markets, (2) internationalization of labor markets and European integration, (3) the welfare state and labor markets, (4) labor markets in transition, (5) the future of work, (6) project evaluation and (7) general labor economics.

IZA Discussion Papers often represent preliminary work and are circulated to encourage discussion. Citation of such a paper should account for its provisional character. 
IZA Discussion Paper No. 373

October 2001

\section{ABSTRACT}

\section{Does the Statutory Overtime Premium Discourage Long Workweeks?}

Using a pooled data set consisting of 20 annual observations on each of eleven major industry groups, I estimate the effects of overtime pay regulation on weekly work schedules. After controlling for workweek trends within industries, the sharp expansions in overtime pay coverage resulting from legislative amendments and Supreme Court decisions produced no discernible impact on overtime hours. This finding is consistent with a model of labor market equilibrium in which straight-time hourly wages adjust to neutralize the statutory overtime premium.

JEL Classification: J33, J38, J23

Keywords: Overtime, work hours, compensating differential

Steve Trejo

Department of Economics

University of Texas

Austin, TX 78712-1173

USA

Tel.: $+1512475-8512$

Fax: +15124713510

Email: trejo@eco.utexas.edu 


\section{Introduction}

In addition to setting the minimum wage, the Fair Labor Standards Act (FLSA) requires that covered workers be paid an overtime wage of at least one and one-half times their straighttime hourly wage for weekly hours worked in excess of 40. The FLSA was enacted in 1938 when labor markets still suffered from the lingering effects of the Great Depression, and the overtime pay provisions were intended to discourage the use of long workweeks and instead encourage firms to replace overtime hours with increased employment. Whether these provisions bring about the intended effects remains an open question.

For overtime pay regulation to have any chance of increasing employment, it must first curtail the use of overtime. Only a few previous empirical studies have examined the response of overtime hours to the statutory overtime premium, and, for reasons discussed below, the results of these studies are inconclusive. From a public policy viewpoint, the scarcity of research on this topic is unfortunate because overtime pay regulation could potentially have an enormous impact on labor markets. In May 1989, for example, 24 percent of the nonsupervisory employees analyzed in this paper worked overtime during the survey week, and overtime hours made up 8 percent of total work hours.

The current paper tries a new approach for estimating the impact of overtime pay regulation on work schedules. In contrast to the cross-sectional focus of existing research, my strategy is to exploit time series variation in the proportion of workers within an industry who are subject to the overtime pay provisions of the FLSA. This strategy has the advantage of controlling for workweek differences across industries that are unrelated to overtime pay 
regulation. Changes in FLSA overtime pay coverage have occurred primarily because of legislative amendments and Supreme Court decisions, and these coverage changes are particularly useful for analytical purposes because they typically take place as large and sudden discrete jumps. Since the inception of the FLSA, the parameters of overtime pay regulation have remained fixed at time and a half for weekly hours of work beyond 40 , so examining coverage changes is a natural way to identify effects of the statutory overtime premium. ${ }^{1}$

\section{Modeling the Effects of Overtime Pay Regulation}

This section spells out the empirical implications of two alternative approaches to modeling the consequences of overtime pay regulation. Both approaches are very simple, but they yield strikingly different outcomes and are therefore useful in delineating the range of likely responses to overtime pay regulation. Labor demand models predict that introducing a statutory overtime premium will lower the incidence of overtime work schedules, increase the prevalence of 40-hour workweeks, and reduce the amount of overtime assigned by firms that continue to use long workweeks. Conversely, a compensating differential framework implies that hourly wage flexibility can rob overtime pay regulation of any substantive impact.

\section{A. Labor Demand Models}

For the most part, economists have analyzed overtime pay regulation using static models of the firm's demand for workers and hours (Ehrenberg 1971; Hart 1984, 1987). Consider a

\footnotetext{
${ }^{1}$ Actually, the standard workweek beyond which time and a half must be paid did change in the years immediately following enactment of the FLSA: it was initially set at 44 hours in 1938, then fell to 42 hours in 1939, and has been 40 hours since 1940. Costa (2000) uses this variation to identify the initial impact of the FLSA on work hours in wholesale trade. The FLSA regu lates weekly but not daily work schedules, in that the statutory overtime premium is required only for weekly hours beyond 40, regardless of how many hours are worked in any given day. For a relatively small proportion of workers, some union contracts and a few states have supplemented the FLSA by also requiring overtime pay for daily hours of work in excess of a particular threshold, such as eight hours. See
} 
firm whose production technology can be described by the production function $Q=F(N, H)$, where $Q$ is output, $N$ is the number of employees, and $H$ is the length of the workweek (assumed to be the same for all employees). ${ }^{2}$ Because $N$ and $H$ enter the production function as separate arguments, this specification allows the marginal product of an additional man-hour of work to differ depending on whether it is obtained by expanding employment or through increased utilization of the existing work force.

In the presence of overtime pay regulation, the firm's total labor costs $C$ are

$$
\begin{array}{ll}
C=w N H+v N, & \text { if } H \leq \bar{H}, \\
C=w N \bar{H}+b w N(H-\bar{H})+v N, & \text { if } H>\bar{H},
\end{array}
$$

where $w$ is the straight-time hourly wage rate, $b$ denotes the overtime premium required by law, $\bar{H}$ is the level of weekly hours at which the overtime premium must go into effect, and $v$ represents all quasi-fixed labor costs. Quasi-fixed labor costs vary solely with the number of employees, rather than with hours worked. Examples of such costs include personnel and training expenditures, various fringe benefits, and statutory social welfare payments with low ceilings (see Hart (1984) for a detailed discussion of these costs).

Labor demand models typically assume that the firm chooses $N$ and $H$ while treating $w$, $v, b$, and $\bar{H}$ as exogenous. For employees subject to the overtime pay provisions of the FLSA, current law requires an overtime wage of at least one and one-half times the straight-

\footnotetext{
Bhattacharya, DeLeire, and MaCurdy (2000) and Hamermesh and Trejo (2000) for analyses of California's daily overtime law.

${ }^{2}$ For simplicity, labor demand models of this type usually posit identical workers.
} 
time hourly wage for weekly hours worked in excess of 40 (i.e., $b \geq 1.5$ and $\bar{H} \leq 40$ ). ${ }^{3}$ Notice that the wage structure imposed by the FLSA creates a kink in the firm's cost function at the standard workweek $\bar{H}$. Because of this kink, the firm's decision involves comparing the solutions to various subproblems. Consider the following indirect profit functions (where the price of output has been normalized to unity):

$$
\begin{aligned}
& \Pi^{1}(w, v)=\max _{N, H} F(N, H)-w N H-v N, \\
& \Pi^{2}(w, v, \bar{H})=\max _{N} F(N, \bar{H})-w N \bar{H}-v N, \\
& \Pi^{3}(w, v, b, \bar{H})=\left\{\begin{array}{c}
\max _{N, H} F(N, H)-w n \bar{H}-b w N(H-\bar{H})-v N, \\
\text { subject to } H>\bar{H} .
\end{array}\right.
\end{aligned}
$$

$\Pi^{1}$ is the relevant maximization problem in the absence of overtime pay regulation. If the solution to this problem yields an optimal workweek $H^{*} \leq \bar{H}$, then this solution is globally optimal and the firm will not assign overtime. If instead $H^{*}>\bar{H}$, then the firm compares $\Pi^{2}$ with $\Pi^{3}$. Profits are $\Pi^{2}$ when the corner solution $H=\bar{H}$ is adopted to avoid paying premium rates for overtime, whereas utilizing overtime yields profits of $\Pi^{3}$. If $\Pi^{3}>\Pi^{2}$, then the firm assigns overtime; otherwise, it chooses a workweek of exactly $\bar{H}$. From equations (3)-(5) it is clear that $\Pi^{1}$ and $\Pi^{2}$ are independent of the overtime premium while $\Pi^{3}$ is monotonically decreasing in it (by the envelope theorem, $d \Pi^{3} / d b=-w N(H-\bar{H})<0$ ). Therefore increases in the overtime premium enlarge the kink in the cost function and make the firm more likely to forgo overtime in favor of the corner solution $\bar{H}$.

\footnotetext{
${ }^{3}$ Although $b=1.5$ and $\bar{H}=40$ are by far the most common overtime pay parameters observed in the United States, union contracts sometimes specify an overtime premium of double time or a standard workweek of less than 40 hours (Trejo 1993).
} 
Labor demand models thus imply that the overtime pay provisions of the FLSA produce systematic effects on the distribution of weekly hours of work. In particular, the simple model discussed above predicts that overtime pay regulation should reduce the proportion of workers on overtime work schedules, increase the proportion of workers with 40-hour workweeks, and not affect the prevalence of workweeks below 40 hours. ${ }^{4}$

In addition, labor demand models imply that the introduction of premium pay for overtime should shorten the workweeks of those workers who continue to put in overtime. This result can be derived by differentiating the first-order conditions associated with the optimization problem given in equation (5) and showing that, under standard conditions, the comparative statics derivative $d H^{*} / d b$ is negative. To see the intuition behind this result, rearrange equation (2) to write total labor costs in the presence of overtime as

$$
C=b w N H+[(1-b) w \bar{H}+v] N .
$$

Equation (6) expresses labor costs as a linear function of man-hours $(\mathrm{NH})$ and employment $(\mathrm{N})$. This formulation makes clear that an increase in the overtime premium raises man-hour costs while at the same time reducing (since $b>1$ ) those costs which vary solely with the level of employment. Thus overtime pay regulation raises the marginal cost of overtime hours relative to the marginal cost of hiring an additional worker, so cost-minimizing firms substitute employment for overtime hours.

Of course, increases in the overtime premium also raise the marginal cost of production,

\footnotetext{
${ }^{4}$ Richer models of labor demand that incorporate production substitution between part-time and full-time workers can accommodate the possibility that overtime pay regulation affects the incidence of part -time work schedules (see Hart (1987, pp. 165-176)). On the empirical front, Owen (1979) and Ehrenberg, Rosenberg, and Li (1988) attempt to estimate relative supply and demand functions for part-time and full-time workers, taking into account differences in the cost and productivity of the two types of workers.
} 
thereby generating scale effects. With output endogenous, increasing the overtime premium will reduce overtime hours so long as the scale effect is nonperverse, but the net impact on employment is indeterminate because of conflicting substitution and scale effects. Similar remarks apply when capital is variable, because increasing the overtime premium encourages substitution out of labor inputs and into capital (Nussbaum and Wise 1977). Therefore, labor demand models predict that the introduction of an overtime premium will reduce overtime hours among those who work overtime both before and after the legislative change.

\section{B. A Compensating Differential Model}

The labor demand models described above completely ignore labor supply considerations, and in the present context it is not obvious how to integrate supply and demand into an equilibrium framework. Consider, for example, standard labor supply models in which workers' optimizing choices of consumption and leisure determine work hours. Introducing premium pay for overtime into these models produces results opposite those of labor demand models. Because an overtime premium raises the marginal wage without greatly affecting the average wage, the substitution effect is likely to dominate the income effect and lead workers to supply more overtime hours in response to overtime pay regulation (Filer, Hamermesh, and Rees 1996, pp. 69-71). With firms desiring shorter workweeks and workers wanting longer ones, what is the new labor market equilibrium?

One way out of this problem is to view the workweek as a job aspect over which both firms and workers have preferences, with compensating wage differentials arising in equilibrium for jobs with differing hours of work (Lewis 1969, Rosen 1974). Under this alternative characterization of the labor market, differentials in straight-time hourly wages could arise to 
render overtime pay regulation almost completely inconsequential. ${ }^{5}$

Think of a job as a package of weekly hours of work and weekly earnings. The FLSA mandates that weekly hours of work in excess of 40 be compensated at a rate at least one and one-half times the straight-time hourly wage, but the Act does not regulate the straight-time wage except to require that it not fall below the legal minimum wage. So long as hourly wage rates are flexible, the overtime law does not in any way restrict the ability of workers and firms to contract over packages of weekly hours and earnings. Changes in the overtime premium or standard workweek set by law could generate perfectly offsetting changes in straight-time hourly wages so as to leave weekly hours and earnings unchanged.

The standard formulations of preferences imply that, holding weekly hours of work constant, both firms and workers are indifferent between combinations of straight-time and overtime wage rates that result in the same level of weekly earnings. Suppose that, in the absence of overtime pay regulation, a given employee works $H_{0}>\bar{H}$ hours and is paid $w_{0}$ for each hour, so that weekly earnings are $Y_{0}=w_{0} H_{0} . \quad Y_{0}$ and $H_{0}$ are the quantities that the firm and the worker jointly care about, and the two parties can be expected to somehow come to an agreement over the values of these variables. Regardless of exactly how the initial earningshours package is determined, this package is still available when overtime pay regulation is introduced. To maintain the initial job package in the presence of a statutory overtime premium, the new straight-time wage rate $w_{1}$ is set so as that

$$
Y_{0}=w_{1}\left[\bar{H}+b\left(H_{0}-\bar{H}\right)\right] .
$$

\footnotetext{
Trejo (1991).
}

${ }^{5}$ This possibility is discussed by Ehrenberg and Schumann (1982, pp. 36-38), Owen (1989, pp. 46-47), and 
In particular, this is accomplished by choosing a straight-time wage of

$$
w_{1}=\frac{w_{0} H_{0}}{\bar{H}+b\left(H_{0}-\bar{H}\right)} .
$$

The preceding argument has challenged the implicit assumption of labor demand models that the straight-time hourly wage is independent of overtime pay regulation. This alternative approach suggests that flexibility of the straight-time wage may be sufficient to neutralize a statutory overtime premium. Whatever levels initially chosen for $Y$ and $H, w$ is free to adjust to changes in $b$ and $\bar{H}$ so as to maintain $Y$ and $H$ at their initial levels. This extra degree of freedom potentially allows weekly hours, weekly earnings, and employment to be unaffected by the overtime pay provisions of the FLSA.

Of course, to the extent that overtime hours vary from week to week while the straighttime wage rate remains fixed, the simple static story just told is incomplete (see Trejo (1991) for further discussion). The highly stylized setup considered here is only intended to illustrate that a compensating differential model of labor market equilibrium can generate implications about the effects of overtime pay regulation which differ dramatically from those produced by the standard labor demand framework. In fact, it is possible for a statutory overtime premium to have no effect at all on work schedules or employment. This possibility and the wide range of outcomes supported by existing models of overtime pay regulation make it essential for policy purposes to have credible empirical estimates of these effects. 


\section{Previous Research}

To date, only a few studies have tried to estimate the effect of overtime pay regulation on overtime hours. Ehrenberg and Schumann (1982) provide representative estimates and also critically review previous work. Almost all studies use cross-sectional data at the establishment level from various years of the Employer Expenditure for Employee Compensation surveys. The basic empirical methodology is to regress annual overtime hours per employee on control variables and the ratio of quasi-fixed labor costs to the overtime wage. Typical findings indicate a statistically significant positive association across establishments between this ratio and the use of overtime.

This result, however, is not necessarily evidence on the effects of overtime pay regulation. Ehrenberg and Schumann (1982) show that the result is driven by the strong correlation between quasi-fixed labor costs and overtime hours: when quasifixed labor costs and the overtime wage enter the regressions separately rather than in ratio form, the coefficients on the overtime wage often have the wrong sign and tend to be statistically insignificant. Moreover, these data dis play very little variation in the overtime premium with which to estimate directly the effects of overtime pay regulation. Firms in these data almost uniformly report paying an overtime premium of time and a half, so nearly all of the variation across establishments in the overtime wage is due to interfirm differences in the straight-time wage.

In an earlier paper (Trejo 1991), I attempt to test the conflicting implications of the labor demand and compensating differential models of overtime pay regulation by analyzing data on the hourly wages, weekly earnings, and weekly hours of individual workers. The results suggest that neither model provides a complete explanation of observed outcomes. For 
example, straight-time wages appear to adjust by a significant amount in the direction predicted by the compensating differential model, but by less than half as much as would be necessary to fully offset the statutory overtime premium.

My previous study measures the effects of overtime pay regulation by comparing covered and noncovered workers using microdata from the Current Population Survey (CPS). Two problems arise with this approach. First, from the information provided in the CPS it is sometimes impossible to determine whether or not a given worker is subject to the overtime pay provisions of the FLSA. Second, and more importantly, the covered and noncovered sectors are very dissimilar in terms of their industrial and occupational composition, so it is difficult to control convincingly for all extraneous differences between the sectors and thereby isolate the true impact of overtime pay regulation.

To avoid some of the problems associated with existing estimates, the current paper adopts a different approach for identifying the effects of overtime pay regulation on weekly work schedules. My strategy is to exploit time series variation in the proportion of workers within an industry who are subject to the overtime pay provisions of the FLSA. ${ }^{6}$ Changes in FLSA coverage rates are arguably exogenous in that they arise primarily because of legislative amendments and Supreme Court decisions.

\footnotetext{
${ }^{6}$ I recently came across two studies that use approaches similar to mine for identifying the impact of the overtime pay provisions of the FLSA, but these studies focus on particular sectors of the economy, whereas I analyze a broader range of industries. Costa (2000) investigates how hours of work in wholesale trade responded to the FLSA in the decade after its enactment in 1938, and she notes reasons why federal overtime pay regulation might today have different effects than it did initially. Johnson (2000) studies the impact of the FLSA on state and local government workers. Consistent with what I report below, he finds that imposition of a statutory overtime premium does not reduce overtime hours in the public sector.
} 


\section{Data on FLSA Coverage and Overtime Hours}

Estimates of coverage under FLSA overtime pay regulation are available from the reports entitled Minimum Wage and Maximum Hours Standards Under the Fair Labor Standards Act submitted each year to Congress by the Employment Standards Administration of the U.S. Department of Labor. ${ }^{7}$ These reports provide a consistent annual series over the period $1970-1989^{8}$ for each of eleven major industry groups: agriculture; mining; construction; manufacturing; transportation and public utilities; wholesale trade; retail trade; finance, insurance, and real estate (FIRE); services (except domestic service); domestic service (in private households); and government. ${ }^{9}$ The first ten industries refer only to the private sector, whereas the government category excludes the military but includes all other public sector activities, whether at the federal, state, or local level.

Because the FLSA does not apply to the self-employed, this segment of the work force is absent from the coverage estimates reported by the Department of Labor. Section 13(a)(1) of the FLSA exempts from minimum wage and overtime pay regulation anyone employed in an

\footnotetext{
${ }^{7}$ Technically, workers are "covered" by the FLSA if they fall under the purview of the legislation, but certain covered workers may be "exempt" from some or all of the provisions of the Act. Workers are subject to the overtime pay provisions of the FLSA only if they are both covered by the Act and not exempt from its overtime pay provisions (Sellekaerts and Welch 1984). Throughout this paper, however, I use the term "covered" as meaning "subject to the overtime pay provisions of the FLSA". For my purposes, the technical distinction between those not covered by the FLSA and those who are covered but exempt is unimportant, and the usage of the term "covered" that I adopt is common in the social science literature. Indeed, the Employment Standards Administration of the U.S. Department of Labor adopts this same usage when presenting its estimates of "coverage" under the minimum wage and overtime pay provisions of the FLSA (U.S. Department of Labor 1998, pp. 21-22).

${ }^{8}$ FLSA coverage estimates are available for 1990 and later years, but these estimates are not comparable to earlier estimates because of substantial changes in the estimation methodology (U.S. Department of Labor 1998, p. 22 and Appendix C). Therefore, I employ only the coverage estimates through 1989.

${ }^{9}$ For 1979, data are available on coverage under the minimum wage but not the overtime pay provisions of the FLSA. Because workers subject to overtime pay regulation constitute a subset of those subject to the minimum wage, the two coverage series move very closely together (within-industry correlation coefficients exceeding .90).

Accordingly, I computed overtime pay coverage rates for 1979 by interpolating between the corresponding rates for
} 
executive, administrative, or professional capacity, and also anyone employed as an outside salesperson. So that movements in FLSA coverage rates are not driven by changes in the size of this unique group of workers, these occupations are excluded from analysis. ${ }^{10}$

For the remaining population consisting of civilian, nonsupervisory employees, Figure 1 plots the overall proportion of these workers in each year who were subject to the overtime pay provisions of the FLSA. Over this twenty-year period, the proportion covered climbed from 66 percent in 1970 to 84 percent in 1989, with considerable variation in between. However, the aggregate coverage rate shown in Figure 1 masks the disparate patterns of change that occurred within individual industries.

Figure 2 displays the FLSA overtime pay coverage series for three selected industries. The top line in Figure 2 represents the coverage rate in manufacturing. Coverage was virtually complete with almost no variation over the sample period. The situation was very similar for several other industries not pictured in Figure 2: mining, construction, wholesale trade, and FIRE. The overtime pay provisions of the FLSA have never applied to agriculture, so for this industry the coverage rate was zero for the entire period.

The line in Figure 2 with the relatively gradual upward slope represents retail trade. The large jump in coverage is due to the 1977 FLSA amendments which eliminated the overtime exemption that had existed for restaurant employees. The smaller changes in coverage mainly reflect the effects of inflation on the annual sales volume test used to exempt small firms in this

1978 and 1980, with the movement in minimum wage coverage rates over 1978-1980 used to construct the interpolation factors for each industry. Fortunately, no important coverage changes occurred in 1979 or 1980.

${ }^{10}$ If instead workers in these occupations are retained in the sample, I obtain results similar to those reported below. 
industry. Because the sales volume test also applies to firms in the services industry, a similar coverage pattern shows up there as well, except that for services the jump in coverage occurred with the 1974 rather than the 1977 FLSA amendments. ${ }^{11}$ Domestic service workers were exempt from the FLSA until 1974, and since then the coverage rate for this industry has hovered around 60 percent. For transportation and public utilities, overtime pay coverage rose very gradually over the sample period from 57 to 64 percent.

The third and final line in Figure 2 depicts the unique situation of government. The first jump reflects the 1974 amendments which extended minimum wage and overtime pay regulation to virtually all public sector activities left uncovered by the 1966 amendments. The sharp drop in 1976 is due to the Supreme Court ruling in National League of Cities v. Usery (426 U.S. 833) that the FLSA could not be applied to state and local government employees working in traditional government functions. With its February 1985 decision in Garcia v. San Antonio Metropolitan Transit Authority et al (105 S.Ct. 1005), the Supreme Court overturned its earlier ruling, and this explains the second jump in the FLSA coverage of public employees. ${ }^{12}$

The FLSA coverage estimates are supposed to be for September of each year, but the precise dating of a couple of the coverage changes is open to question. For example, the 1977 FLSA amendments did not go into effect until January 1978, yet the coverage series for retail trade rises sharply in 1977 rather than 1978. In a similar vein, the reported coverage rate of

\footnotetext{
${ }^{11}$ Starting in 1990, the annual sales volume test was extended to other industries beyond retail trade and services (Card and Krueger 1995, p. 115).

${ }^{12}$ In response to complaints from state and local governments about the financial impact of this decision, Congress enacted FLSA amendments that allow state and local government employees to receive compensatory time off instead of premium pay for overtime. Such "comp time" must be awarded at the rate of one and one-half hours for each overtime hour worked, however, so the resulting effects should be similar to those generated by an overtime pay requirement.
} 
government employees shoots up in 1985 because of the Supreme Court's Garcia decision, even though the 1985 FLSA amendments delayed enforcement in the state and local sectors until April 1986. The empirical results are not sensitive to the way in which these issues are handled, so the analysis that follows makes use of the FLSA coverage data as published.

A corresponding set of industry by year data on work schedules and demographic characteristics was computed from the May CPS tapes for 1970-1989. ${ }^{13}$ The sample for these computations consists of individuals ages 16 and above who were at work during the survey week. Exclusions of the self-employed, supervisory employees, and outside salespeople were made in order to match the FLSA coverage data as closely as possible. Since the CPS data are for the survey week in May of each year, these data predate the FLSA coverage data by about four months. Fortunately, all but one of the legislative amendments and Supreme Court decisions that significantly changed FLSA overtime pay coverage went into effect by May 1 of the relevant year. The lone exception is the Supreme Court ruling in June 1976 that initially exempted state and local government workers from the FLSA, but revising the coverage series for public sector workers to synchronize with the CPS data on work hours has little effect on the empirical results. Indeed, lagging the published FLSA coverage data by one year for every industry produces estimates similar to those reported below.

For each of the eleven industry groups and for the first and last years of the sample, Table 1 presents selected data pertaining to overtime. The first two columns give the FLSA overtime pay coverage rates discussed above. The next two columns report the fraction of

\footnotetext{
${ }^{13}$ The CPS sampling weights were used in these calculations, but unweighted calculations yield similar results.
} 
workers who put in overtime during the survey week, with overtime hours defined as weekly hours of work beyond 40. Also shown are the average number of weekly overtime hours worked by overtime workers and weekly overtime hours per worker, where the latter average is computed over all workers in an industry, with individuals working 40 hours or less assigned zero hours of overtime. Weekly overtime hours per worker is simply the product of overtime incidence and the average length of overtime workweeks, so the three measures of overtime work displayed in the table are related by an identity (see footnote 20 below). Finally, the last two columns of Table 1 report the sample sizes on which the CPS calculations are based.

For these same four variables, Table 2 reports the means and standard deviations of the annual observations from 1970-1989. Once again, the statistics are shown separately by industry and also when the data from all industries are aggregated.

Together, Tables 1 and 2 reveal the amount of time series variation in the key variables. These tables indicate that five of the eleven major industry groups experienced significant changes in FLSA overtime pay coverage over the sample period: transportation, retail trade, services, domestic service, and government. Table 1 shows that coverage expanded in all of these industries, and the corresponding changes in work hours suggest that the statutory overtime premium did little to curb the use of overtime. Of the five industries in which FLSA coverage widened substantially, only retail trade experienced a decline in overtime hours per worker. Of course, these simple comparisons do not control for the business cycle and other factors that cause overtime hours to fluctuate. The empirical work reported below provides a systematic analysis of these data. 


\section{Empirical Analysis}

Using the industry time series data just described, this section presents new estimates of the effects of overtime pay regulation on weekly work schedules. The labor demand framework discussed in Section II predicts that increases in FLSA coverage should lower the incidence of overtime work and reduce the length of the overtime work schedules which remain, while at the same time increasing the prevalence of 40-hour workweeks. Conversely, if straight-time wage rates respond to a statutory overtime premium in the manner suggested by the compensating differential model, then none of these effects should occur.

\section{A. Regressions in Levels}

Table 3 reports initial estimates of the determinants of work schedules and average weekly overtime hours. As described above, the data consist of 20 annual observations on each of eleven major industry groups, resulting in a total sample size of 220 for the pooled data set that is analyzed. Because the dependent variables represent industry/year averages computed from the CPS, all of the least squares regressions in Table 3 are weighted to reflect the microdata sample sizes used in these calculations. In the first three columns, the dependent variables are the proportions of workers with part-time, full-time, and overtime workweeks, respectively. Part-time workers are defined as those working less than 40 hours during the survey week, full-time workers are those working exactly 40 hours, and overtime workers are those working more than 40 hours. ${ }^{14}$ For the entire CPS sample that includes workers in all

\footnotetext{
${ }^{14}$ It is only for expository convenience that I designate as "part-time" workers those with workweeks less than 40 hours. My sole purpose in doing so is to distinguish such workers from those with workweeks of exactly 40 hours, because labor demand models suggest that overtime pay regulation should affect these two groups of workers differently. For the same reason, "full-time" workers are narrowly defined to reflect the kink in the wage structure at 40 hours that is imposed by the overtime pay provisions of the FLSA. My use of the terms "part time" and "full time" is
} 
industries and years, the mean proportions are as follows: 33.4 percent worked part time, 44.6 percent worked full time, and 22 percent worked overtime.

The proportions of workers in the various workweek categories sum to unity within each industry/year cell, and therefore an alternative estimation approach is generalized least squares applied to the multinomial logit model for grouped data (Theil 1970; Parks 1980). The primary advantage of the logit specification in this context is that it constrains the predicted outcomes to lie in the unit interval appropriate for proportions. In the current application, however, the tight-fitting linear models presented in Table 3 yield predicted proportions that track the observed proportions quite closely and never fall outside the unit interval. Moreover, logit estimates of the marginal effects of the independent variables, calculated at the overall sample mean proportions of workers in each hours category, are very similar to the corresponding weighted least squares coefficients reported in Table 3. Because the coefficients of linear models are easier to interpret, I report only estimates of these models throughout the paper. ${ }^{15}$

Another estimation issue is the possibility of autocorrelation in the industry time series. Durbin-Watson statistics suggest that this is not a major problem, however, and estimates that correct for industry-specific first-order serial correlation are quite similar to those reported here.

The key explanatory variable in Table 3 is the FLSA overtime pay coverage rate, which

not intended to represent the usual distinction between workers with different degrees of attachment to the labor market.

${ }^{15}$ An additional advantage of linear models for grouped data is that, strictly speaking, logit estimates are consistent only when the independent variables do not vary within groups (Amemiya 1985, p. 278). In the present context, for example, this means that all workers in a particular industry/year cell must have the same demographic characteristics and FLSA overtime pay coverage status. This condition clearly does not hold in my data, and it is rarely satisfied in economic applications involving grouped data. 
measures the extent of overtime pay regulation in a given industry at a particular point in time. Other independent variables include demographic characteristics computed for each industry/year cell from the CPS tapes. These variables describe how the work force varies across industries and over time with respect to attributes such as age, gender, race, marital status, education, occupation, and geographic region of residence. Note that the key independent variable - FLSA overtime pay coverage — is available only by industry and year, not at the level of the individual worker. Therefore, I am not throwing away important variation by aggregating the CPS microdata to the industry/year level in constructing the other independent variables and the dependent variables. ${ }^{16}$

Also included in the regressions are industry dummies to control for technological and other differences across industries that do not vary over the sample period, and year dummies to control for secular trends and effects related to the business cycle. Year dummies control for business cycle effects that are national in scope, but not for those that are industry-specific. To gauge the importance of this limitation, I experimented with two different measures of economic activity at the industry level: gross domestic product (GDP) and the unemployment rate. ${ }^{17}$ Adding either of these variables to the regressions had little effect on the estimated impact of overtime pay coverage or on the overall pattern of results. Using these variables, however, requires aggregation of some industries (in particular, both the GDP and unemployment data do

\footnotetext{
${ }^{16}$ The CPS microdata could be useful in estimating the effects of the demographic characteristics on the dependent variables. As noted below, however, the estimated coefficients of the FLSA coverage rate are similar when the demographic variables are excluded from the regressions, so it is unlikely that aggregation is affecting my estimates of the impact of overtime pay regulation. Moreover, aggregation greatly reduces the computational burden, as the underlying microdata contain about three-quarters of a million observations.
} 
not allow domestic service to be distinguished from the rest of the services industry, and the unemployment data also combine wholesale trade with retail trade). Therefore, I will report the results from regressions that do not include these additional variables.

From the viewpoint of labor demand models, conspicuously absent from the list of explanatory variables are data on straight-time hourly wage rates and quasi-fixed labor costs. Unfortunately, suitable industry time series for these variables do not exist. ${ }^{18}$ Nonetheless, I did experiment with somewhat crude proxies, and adding these proxy variables to the regressions had little impact on the estimated effects of overtime pay regulation. ${ }^{19}$ The other control variables — the demographic variables and the industry and year fixed effects—probably capture much of the relevant variation in straight-time wages and quasi-fixed labor costs.

The estimated effects of the demographic variables reported in Table 3 are sensible and generally in accord with similar estimates obtained from microdata (Trejo 1993). For example, female workers are less likely to work a standard 40-hour week, and industries with more

\footnotetext{
${ }^{17}$ The industry -specific GDP data are from Table B-12 on page 432 of the February 1999 Economic Report of the President, and the industry-specific unemployment rates were downloaded from the Bureau of Labor Statistics web site: http://stats.bls.gov/webapps/legacy/cpsatab5.htm.

${ }^{18}$ The CPS provides information on the straight-time wages of those workers paid by the hour, but these data do not appear until 1973, and after 1978 they are available for only a quarter of the sample. Data on average hourly earnings are available from various sources, such as the National Income and Product Account (NIPA) tables and the payroll surveys conducted by the Bureau of Labor Statistics. Because these data series fail to separate straight-time pay from overtime premiums, however, they introduce a spurious positive correlation between hourly earnings and overtime work. The NIPA tables also provide data on nonwage labor compensation, but as a measure of quasi-fixed labor costs these data suffer from two main problems. First, some components of nonwage compensation increase with hours of work, and therefore these components do not represent quasi-fixed costs. Second, some components of nonwage compensation, such as health and retirement benefits, are determined endogenously along with work schedules and the rest of the job package.

${ }^{19}$ For proxy variables, I constructed measures of average hourly earnings and nonwage labor costs per worker from the NIPA tables, using the GNP deflator for personal consumption expenditure to convert the figures into real dollars. Because the NIPA data on nonwage compensation do not distinguish domestic service from other services, the CPS data and FLSA coverage data for these industry groups were aggregated for the purposes of this analysis. According to labor demand models, higher straight-time wages encourage shorter workweeks by raising variable employment costs, and increases in quasi-fixed labor costs should lengthen workweeks as firms try to economize on
} 
educated workers and those with a high proportion of blue-collar workers assign less part-time work and more overtime. Some of the demographic effects are imprecisely estimated, perhaps because these variables tend to change slowly over time within industries, so they are collinear with the industry dummies. It is important to note, however, that this collinearity is not affecting the key results. The estimated coefficients of the FLSA coverage rate are similar when the demographic variables are excluded from the regressions. The fact that the industry and year dummies do a good job in these regressions of controlling for the effects of observable demographic differences across industries and changes over time provides some hope that these dummies may also control for unobservable differences and changes.

Turning now to the impact of overtime pay regulation, expanded FLSA coverage appears to increase part-time work and reduce full-time and overtime work. The point estimates imply that changing an industry from completely uncovered to fully covered raises by 3.7 percentage points the proportion of workers with workweeks under 40 hours, lowers the proportion with 40-hour workweeks by 1.2 percentage points, and lowers the proportion working overtime by 2.5 percentage points. This FLSA-induced decline in the prevalence of overtime represents an 11 percent reduction when measured against the mean proportion working overtime in the overall sample. The estimated effects of the statutory overtime premium on part-time and overtime work are statistically significant, whereas the effect on full-time work is not.

these costs (Hart 1984). The signs on the estimated coefficients of the proxy variables support these predictions, although the effects are not statistically significant at the five percent level. 
The estimates just discussed suggest that overtime pay regulation lowers the incidence of overtime workweeks, but these estimates do not address the question of whether FLSA coverage reduces the number of overtime hours worked by those who continue to work overtime. To get at this question, the dependent variable in the last column of Table 3 is the natural logarithm of weekly overtime hours per worker. Because this average is computed over all workers in an industry (including those who worked zero hours of overtime), the regression coefficients measure the total impact of the independent variables on average weekly overtime hours, which includes both the effect on overtime incidence and the effect on workweek length conditional upon working overtime.

The coefficient on FLSA coverage in the last column of Table 3 indicates that the overtime pay provisions reduce overtime hours per worker by about 12 percent. Recall that the coverage coefficient reported in the third column implies that, even if there were no change in the workweeks of those who continue to work overtime, the induced decline in the proportion of workers on overtime could alone account for an 11 percent fall in overtime hours. Consequently, these estimates suggest that the impact of overtime pay regulation on overtime hours works almost entirely through its effect on overtime incidence. ${ }^{20}$

\footnotetext{
${ }^{20}$ To see this point, start with the identity $E(O T)=\operatorname{Pr}(O T>0) E(O T \mid O T>0)$, where $O T$ represents weekly overtime hours. Differentiating both sides of the identity with respect to $C$, the fraction of an industry's workers covered by FLSA overtime pay regulation, and dividing through by $E(O T)$ yields

$$
\frac{\frac{d E(O T)}{d C}}{E(O T)}=\frac{\frac{d \operatorname{Pr}(O T>0)}{d C}}{\operatorname{Pr}(O T>0)}+\frac{\frac{d E(O T \mid O T>0)}{d C}}{E(O T \mid O T>0)} .
$$

In words, the percentage change in average weekly overtime hours induced by an increase in FLSA coverage is equal to the sum of the percentage changes in overtime incidence and the average length of overtime workweeks. Only if coverage effects on overtime workweeks are negligible will the percentage effects on overtime hours per worker and overtime incidence be similar in magnitude, as implied by the estimates in Table 3. Direct confirmation of this result
} 
Before accepting the FLSA coverage effects reported in Table 3, however, consider Figures 3 through 13. For each industry, these figures plot the time series of coverage and the proportions of the work force with part-time, full-time, and overtime workweeks. Focus in particular on Figures 7, 9, 11, 12, and 13, which show the plots for the five industries with important coverage changes during the sample period. Two points emerge from these figures. First, even though four of these five industries (all but transportation) experienced discrete jumps in overtime pay coverage, changes in work schedules were gradual and do not coincide closely with the coverage shifts. Second, Figure 13 strongly suggests that the dramatic coverage shifts that occurred in the public sector had no effect on work schedules.

To probe the apparent discrepancy between these graphs and the results in Table 3, Table 4 presents the estimated effects of FLSA overtime pay coverage in three alternative regression specifications. The sample, dependent variables, and control variables are the same as in Table 3.

The first specification in Table 4 allows the effects of overtime pay coverage to differ for the public and private sectors. In all cases the government interaction term is opposite in sign and similar in magnitude to the main effect for coverage, which suggests that public sector work schedules are unaffected by overtime pay regulation. ${ }^{21}$ Notice, however, that estimated

comes from a regression similar to the one reported in the last column of Table 3, with the dependent variable changed to (the log of) average weekly overtime hours worked by overtime workers (instead of average weekly overtime hours among all workers, including those with zero hours of overtime). In this regression, the estimated coefficient on the FLSA coverage rate is small and statistically insignificant. Note, however, that this regression suffers from a potentially severe selection bias, because workers with relatively few overtime hours are more likely cut back to a 40 -hour workweek in response to FLSA coverage, and in that event these individuals drop out of the sample of overtime workers used in constructing the dependent variable. For this reason, I prefer the regression reported in Table 3 in which the dependent variable is average weekly overtime hours among all workers, and I infer the impact of overtime pay regulation on the average length of overtime workweeks using the equation presented earlier in this footnote.

${ }^{21}$ Johnson (2000) reaches a similar conclusion. 
coverage effects for private sector workers are now huge. For example, these estimates imply that complete FLSA coverage lowers overtime hours per worker in the private sector by 43 percent, with, as before, almost all of this decline due to a reduction in overtime incidence rather than any shortening of overtime workweeks. Because much of the variation in overtime pay coverage that occurred during the sample period took place within the public sector, the tiny coverage effects for government workers predominate when overtime pay regulation is constrained to have the same impact in the public and private sectors.

Do these enormous FLSA coverage effects for private sector workers really represent the causal influence of the statutory overtime premium? Even though overtime pay coverage typically grew in discrete jumps, there is a strong upward trend in coverage for those private sector industries that experienced changes during the sample period. ${ }^{22}$ It is therefore possible that the FLSA coverage variable is merely picking up long-term trends in work schedules for these private sector industries. Because year fixed effects are already included in the regressions, such trends must be specific to the industries with important coverage changes in order to bias estimates of the effects of overtime pay regulation. ${ }^{23}$

Retail trade nicely illustrates the possibility that long-term trends are being mistaken for effects of overtime pay regulation. As shown in Figure 9, this industry experienced during the

\footnotetext{
${ }^{22}$ For industries that experienced important coverage changes, the correlation coefficients between FLSA overtime pay coverage and a linear time trend are as follows: .92 for transportation and public utilities, .92 for retail trade, .87 for services (except domestic service), .68 for domestic service, and .40 for government.

${ }^{23}$ A different but related possibility is that the labor market response to FLSA coverage is not immediate but instead spread over an adjustment period. To investigate this possibility, I added to the regressions within-industry lags of the FLSA coverage rate. Including the lags produced less precise estimates of coverage effects but did not change the general pattern of results. Even with as many as three years of lagged coverage rates, estimates of the overall (i.e., longrun) effects of FLSA coverage are similar to the contemporaneous coverage effects reported in Table 3 and the first specification in Table 4.
} 
sample period a fairly steady increase in the proportion of part-time workers and an equally steady decline in the proportion of overtime workers, and these trends apparently were not disturbed by the large jump in FLSA overtime pay coverage that occurred in 1977. Indeed, retail workweeks have been getting shorter-both in absolute terms and relative to other industries - throughout the postwar period (Oi 1988; Coleman and Pencavel 1993). This development started long before the 1961 and 1966 FLSA amendments introduced widespread minimum wage and overtime pay coverage into retail trade.

To explore this issue, the second specification in Table 4 adds separate linear time trends for the five industries that experienced changes in FLSA overtime pay coverage. These time trends are always jointly significant, and the trend for each particular industry is statistically significant for at least two of the four dependent variables. This specification retains distinct coverage effects for public and private sector workers, and the results again show that such effects are absent for government workers. More importantly, for private sector workers, the estimated FLSA coverage effect on overtime incidence is now essentially zero, and the impact on overtime hours per worker is small and not statistically significant. In addition, the estimated effect of overtime pay coverage on the incidence of part-time work falls to less than 40 percent of what it was in the first specification.

Continuing further along these lines, the last specification in Table 4 presents estimated coverage effects when the industry time trends are generalized to be quadratic rather than linear. To save space, the coefficients on the trend variables are not reported for this specification. The trend variables are jointly significant in every regression, although only for two of the dependent variables - proportion working full time and proportion working overtime-are the 
quadratic terms significant. For government workers, the results are the same as for the first two specifications: there is no indication that overtime pay regulation has any impact in the public sector. For the private sector, adding quadratic terms to the time trends reduces by more than half the estimated magnitude of overtime pay coverage effects on the incidence of part-time and full-time work schedules, as compared to the second specification that includes only linear time trends. For the third specification, the estimated effect of FLSA coverage on overtime incidence continues to be zero, and the coverage coefficient now has a perverse positive sign in the regression that employs average weekly overtime hours as the dependent variable. Moreover, once quadratic time trends are included, none of the FLSA coverage effects are close to being statistically significant.

These results suggest that the earlier estimates (in Table 3 and the first specification in Table 4) showing sizable and statistically significant coverage effects may be largely spurious. After controlling for workweek trends within industries, the sharp expansions in overtime pay coverage resulting from FLSA amendments and Supreme Court decisions produced no discernible impact on overtime hours. Estimates of the first specification in Table 4 imply huge effects of overtime pay regulation on work schedules and average overtime hours in the private sector, but adding industry-specific quadratic time trends to the regressions drastically shrinks estimates of FLSA coverage effects on work schedules and reverses the sign of the estimated coverage effect on overtime hours per worker, with the end result that none of these estimated effects remain statistically significant. Note, however, that distinguishing between public and private sector workers and accounting for industry trends yield standard errors for the FLSA coverage coefficients in Table 4 that are two to four times larger than those in Table 3. 
Evidently, the industry time series analyzed here cannot isolate with much precision the effects of overtime pay regulation, both because there exists relatively little intertemporal variation in FLSA coverage within private sector industries, and also because the coverage changes which did occur are highly correlated with long-term trends in work schedules.

\section{B. First-Differenced Regressions}

First-differenced regressions provide an alternative way of investigating specification issues. Suppose that the "true" equation determining outcome variable $y$ in industry $i$ and year $t$ is as follows:

$$
y_{i t}=\beta C_{i t}+\alpha_{i}+\gamma_{t}+\delta_{i} t+\varepsilon_{i t},
$$

where $C$ denotes FLSA overtime pay coverage, $\beta$ measures the coverage effect, the $\alpha_{i}$ are industry fixed effects, the $\gamma_{t}$ are year fixed effects, and the $\delta_{i}$ represent industry-specific time trends. For ease of exposition, equation (9) includes only linear time trends, omits explanatory variables other than FLSA coverage, and does not allow separate coverage effects for the public and private sectors, but these simplifications are immaterial for the points made below and will be relaxed during empirical implementation.

Taking first differences within industries yields

$$
y_{i t}-y_{i t^{\prime}}=\beta\left(C_{i t}-C_{i t^{\prime}}\right)+\left(\gamma_{t}-\gamma_{t^{\prime}}\right)+\delta_{i}\left(t-t^{\prime}\right)+\left(\varepsilon_{i t}-\varepsilon_{i t^{\prime}}\right)
$$

where $t^{\prime}$ is some year prior to year $t$. Using $\Delta$ to represent within-industry differences between years $t$ and $t^{\prime}$, we can write equation (10) more compactly as

$$
\Delta y_{i t}=\beta \Delta C_{i t}+\gamma_{t}^{*}+\delta_{i} \Delta t+\Delta \varepsilon_{i t},
$$

where the $\gamma_{t}^{*}=\gamma_{t}-\gamma_{t^{\prime}}$ are a new set of year fixed effects and $\Delta t=t-t^{\prime}$ is the length of the 
differences. Because $\Delta t$ is a constant in any particular regression, the $\delta_{i} \Delta t$ in equation (11) are nothing more than industry fixed effects. Notice that the basic form of this equation and the implication that it includes industry fixed effects would not change if equation (9) were generalized to include quadratic or higher-order time trends.

Equation (11) makes the simple point that although differencing within industries eliminates industry effects that are truly fixed (i.e., the $\alpha_{i}$ in equation (9)), it does not eliminate those industry effects that vary with time (i.e., the industry-specific trends). Moreover, if industry-specific trends are present, then industry fixed effects should become more important in differenced regressions as the length of the differences gets longer (i.e., the bigger is $\Delta t$ ), because monotonic trends produce larger changes when they have more time to operate.

To understand the bias that can arise from ignoring industry-specific trends, consider a simplified version of equation (9) in which the term $\delta_{i} t$ is replaced by $\delta D_{i} t$, where $D_{i}$ is a dummy variable identifying those five industries that experienced mon-trivial changes in FLSA overtime pay coverage during the sample period. Instead of allowing separate time trends for each individual industry as in equation (9), the simplified specification restricts trends to be the same within two groups of industries. In particular, the year fixed effects $\left(\gamma_{t}\right)$ capture temporal changes for industries with stable FLSA coverage, and the term $\delta D_{i} t$ lets industries with changing coverage follow a different trend.

For this simplified version of equation (9), differencing within industries yields

$$
\Delta y_{i t}=\beta \Delta C_{i t}+\gamma_{t}^{*}+\delta D_{i} \Delta t+\Delta \varepsilon_{i t} .
$$

Suppose that equation (12) were estimated ignoring the industry trends, so that the term $\delta D_{i} \Delta t$ 
was omitted from the regression. Let $b$ denote the estimated coefficient on $\Delta C_{i t}$ in this misspecified regression. Straightforward analysis of omitted variable bias shows that, under these circumstances,

$$
E(b)=\beta+\delta \lambda \Delta t,
$$

where $\lambda$ is the coefficient on $\Delta C_{i t}$ in the "auxiliary" regression of the omitted variable $D_{i}$ on all of the other independent variables in equation (12) (i.e., $\Delta C_{i t}$ and the year fixed effects $\gamma_{t}^{*}$ ).

Because FLSA overtime pay coverage expanded over time in those industries that experienced coverage changes, $\lambda>0$, and the bias in $b$ will have the same sign as the time trend $\delta$. For example, overtime incidence and overtime hours per worker generally declined in industries with coverage changes (see the relevant trend coefficients from specification (2) in Table 4), which implies that ignoring these trends will produce negatively biased estimates of FLSA coverage effects on overtime hours. Similarly, rising part-time work in industries with changing coverage imparts a positive bias to estimates of the impact of overtime pay coverage on the incidence of workweeks below 40 hours. In both cases, the bias works to make FLSA coverage effects appear larger (in absolute value) than they really are. Finally, note from equation (13) that the magnitude of the bias increases with $\Delta t$, the length of the differences.

To assess the empirical importance of these considerations, Table 5 presents FLSA overtime pay coverage effects from first-differenced regressions of various lengths. These regressions, estimated by weighted least squares, are differenced versions of the levels regressions labeled as specification (1) in Table $4 .{ }^{24}$ The coefficients on the interaction term

\footnotetext{
${ }^{24}$ Because the outcome variables $y_{i t}$ are averages for industry/year cells, their variances are proportional to $1 / n_{i t}$, where $n_{i t}$ is the size of the sample used to compute $y_{i t}$. For this reason, the levels regressions reported in
} 
between overtime pay coverage and the government sector are not reported because they typically imply very small coverage effects in this sector. Of course, the sample size in these regressions shrinks as the differences lengthen, because every year added to the length of the differences eliminates another 11 observations (one from each industry) due to missing values.

The top half of Table 5 reports results from differenced regressions that do not include industry fixed effects. Here, the estimated effects of FLSA coverage tend to increase (in absolute value) as the differences lengthen. For example, the magnitude of the estimated coverage effect on overtime hours per worker is more than three times larger in the regression using ten-year differences than in the regression using two-year differences. This pattern fits the implication of equation (13) that the bias from omitting industry-specific trends should grow with the length of the differences.

Equation (11) indicates that including industry fixed effects in the differenced regressions can account for industry-specific trends, and the bottom half of Table 5 presents estimates from regressions that make this adjustment. Adding industry dummies greatly attenuates and in some cases eliminates the tendency—prominent in the top half of the table—for longer differences to produce larger coverage coefficients. Furthermore, the estimated coverage effects are almost uniformly smaller in the bottom half of Table 5 than in the corresponding regression from the top half of the table. Indeed, the differenced regressions in the bottom half of Table 5 yield estimates of FLSA coverage effects that are roughly similar to estimates from levels regressions that control for industry-specific trends (see specifications (2) and (3) in Table 4).

Tables 3 and 4 are weighted by $n_{i t}$. For the same reason, the regressions in Table 5 , where the dependent variables represent within-industry differences between years $t$ and $t^{\prime}$, are weighted by $n_{i t} n_{i t^{\prime}} /\left(n_{i t}+n_{i t^{\prime}}\right)$. 
Finally, recall from equation (11) that monotonic, industry-specific trends imply that industry fixed effects should become more important in differenced regressions as the differences get longer. This implication is borne out in Table 6 , which reports $F$ statistics for tests of the joint significance of the industry fixed effects in the first-differenced regressions reported in the bottom half of Tabe 5. Listed in parentheses are the associated probability values, which represent the smallest significance level at which the null hypothesis of no industry fixed effects can be rejected. With two-year differences, the industry fixed effects are not statistically significant at the five percent level for any of the dependent variables, whereas with ten-year differences the industry effects are significant for all of the dependent variables. For part-time incidence the industry effects are significant in all regressions with differences of at least four years, and for overtime incidence and overtime hours per worker the industry effects are significant whenever differences are six years or longer. Moreover, for each of the dependent variables, the $F$ statistics that measure the joint significance of the industry fixed effects invariably grow larger as the differences lengthen.

In summary, results from first-differenced regressions support the conclusions drawn earlier from regressions in levels. Analyses that do not control for industry-specific time trends overstate the effects of overtime pay regulation by mistakenly attributing long-term changes in work schedules to rising FLSA coverage. Symptomatic of this bias, estimates of overtime pay coverage effects are larger in differenced regressions that exclude rather than include industry fixed effects, and this pattern becomes more pronounced as the length of the differences increases. These findings indicate that the large and often sudden coverage expansions which occurred during the sample period are only weakly correlated with work schedule changes in 
years close to a coverage shift. Such a result suggests that the stronger correlation between FLSA coverage expansions and longer-term movements in workweeks may be driven by factors other than overtime pay regulation.

\section{Conclusion}

This paper has analyzed the effects of overtime pay regulation on weekly work schedules. A labor demand framework predicts that the introduction of a statutory overtime premium should lower the incidence of overtime work, increase the prevalence of 40-hour workweeks, and reduce the amount of overtime assigned by firms that continue to use long workweeks. Conversely, a compensating differential model of labor market equilibrium suggests that straight-time wage flexibility can prevent the overtime pay provisions of the FLSA from having any impact on hours of work.

The empirical analysis focused on time series variation in the fraction of workers within an industry who are covered by overtime pay regulation. Because FLSA overtime pay coverage typically expanded in discrete jumps caused by legislative amendments and Supreme Court decisions, coverage changes provide potentially useful information for identifying the effects of overtime pay regulation. Regressions estimated on pooled data for eleven major industry groups over 20 years suggest that, after controlling for long-term workweek trends within industries, increases in FLSA coverage did not reduce overtime incidence and overtime hours. Whether estimated in levels or first-differences, the regressions indicate that failure to account for industry-specific trends leads to inflated estimates of the effects of overtime pay regulation, because under these circumstances long-term changes in work schedules are 
mistakenly attributed to rising FLSA coverage. These conclusions should be regarded as tentative, however, because it is difficult to distinguish the impact of FLSA coverage expansions from underlying hours trends. Unfortunately, the industry time series analyzed here cannot isolate with much precision the effects of overtime pay regulation, both because there exists relatively little intertemporal variation in FLSA coverage within private sector industries, and also because the coverage changes which did occur are highly correlated with long-term trends in work schedules.

The empirical findings are consistent with the compensating differential model of overtime pay regulation, and they suggest that raising the statutory overtime premium or expanding FLSA coverage may not have the intended effects of reducing overtime hours and creating additional jobs. With the broad industry groups analyzed here, however, the industryspecific trends make it hard to separately identify the impact of overtime pay regulation. For this reason, future work would be wise to study FLSA coverage changes at a more disaggregate level. As an example, the 1974 FLSA amendments extended overtime pay regulation for the first time to employees of restaurants. Because the restaurant industry underwent changes in overtime pay coverage that the rest of retail trade did not experience, the time series of work schedules and overtime hours for these two sectors should display systematic differences if the statutory overtime premium has important effects. In the event that segments of retail trade can be identified where both cyclical and longer-term shocks to workweeks are similar to those affecting restaurants, then these retail industries would provide a natural control group for estimating the impact of extending overtime pay coverage to restaurant workers. 


\section{References}

Amemiya, Takeshi. Advanced Econometrics. Cambridge, Mass.: Harvard University Press, 1985.

Bhattacharya, Jay; DeLeire, Thomas; and MaCurdy, Thomas. "The California Overtime Experiment: Labor Demand and the Impact of Overtime Regulation on Hours of Work.” Manuscript. Chicago: University of Chicago, 2000.

Card, David, and Krueger, Alan B. Myth and Measurement: The New Economics of the Minimum Wage. Princeton, NJ: Princeton University Press, 1995.

Coleman, Mary T., and Pencavel, John. "Changes in Work Hours of Male Employees, 19401988.” Industrial and Labor Relations Review, January 1993, 46(2), pp. 262-83.

Costa, Dora L. "Hours of Work and the Fair Labor Standards Act: A Study of Retail and Wholesale Trade, 1938-1950." Industrial and Labor Relations Review, July 2000, 53(4), pp. 648-64.

Ehrenberg, Ronald G. Fringe Benefits and Overtime Behavior. Lexington, Mass.: D.C. Heath, 1971.

Ehrenberg, Ronald G., and Schumann, Paul L. Longer Hours or More Jobs? Ithaca, NY: ILR Press, 1982.

Ehrenberg, Ronald G.; Rosenberg, Pamela; and Li, Jeanne. "Part-time Employment in the United States," in Robert A. Hart, ed., Employment, Unemployment, and Labor Utilization. Boston: Unwin Hyman, 1988, pp. 256-81.

Filer, Randall K; Hamermesh, Daniel S; and Rees, Albert E. The Economics of Work and Pay, sixth edition. New York: Harper Collins, 1996.

Hamermesh, Daniel S., and Trejo, Stephen J. "The Demand for Hours of Labor: Direct Evidence from California." Review of Economics and Statistics, February 200, 82(1), pp. 38-47.

Hart, Robert A. The Economics of Non-Wage Labour Costs. London: Allen and Unwin, 1984.

. Working Time and Employment. Boston: Allen and Unwin, 1987. 
Johnson, IV, John H. "The Impact of Federal Overtime Legislation on Public Sector Labor Markets." Manuscript. Urbana-Champaign: University of Illinois, 2000.

Lewis, H. Gregg. "Employer Interests in Employee Hours of Work." Manuscript. Chicago: University of Chicago, 1969.

Nussbaum, Joyce E., and Wise, Donald E. The Employment Impact of the Overtime Provisions of the F.L.S.A. Princeton, NJ: Mathtech, Inc., 1977. NTIS, PB-281386.

Oi, Walter Y. "The Indirect Effect of Technology on Retail Trade," in Richard M. Cyert and David C. Mowery, eds., The Impact of Technological Change on Employment and Economic Growth. Cambridge, MA: Ballinger, 1988, pp. 329-75.

Owen, John D. Working Hours. Lexington, MA: Lexington Books, 1979.

- Reduced Working Hours: Cure for Unemployment or Economic Burden? Baltimore: Johns Hopkins University Press, 1989.

Parks, Richard W. "On the Estimation of Multinomial Logit Models from Relative Frequency Data." Journal of Econometrics, August 1980, 13(3), pp. 293-303.

Rosen, Sherwin. "Hedonic Prices and Implicit Markets: Product Differentiation in Pure Competition." Journal of Political Economy, February 1974, 82(1), pp. 34-55.

Theil, Henri. "On the Estimation of Relationships Involving Qualitative Variables." American Journal of Sociology, July 1970, 76(1), pp. 103-54.

Sellekaerts, Brigitte H., and Welch, Stephen W. "An Econometric Analysis of Minimum Wage Noncompliance.” Industrial Relations, Spring 1984, 23(2), pp. 244-59.

Trejo, Stephen J. "The Effects of Overtime Pay Regulation on Worker Compensation." American Economic Review, September 1991, 81(4), pp. 719-40.

. "Overtime Pay, Overtime Hours, and Labor Unions." Journal of Labor Economics, April 1993, 11(2), pp. 253-78.

U.S. Department of Labor, Employment Standards Administration. Minimum Wage and Overtime Hours Under the Fair Labor Standards Act. Washington, DC: U.S. Government Printing Office, 1998. 
Table 1

FLSA Overtime Pay Coverage and Overtime Hours, by Industry, 1970 and 1989

\begin{tabular}{|c|c|c|c|c|c|c|c|c|c|c|}
\hline \multirow[b]{2}{*}{ Industry } & \multicolumn{2}{|c|}{$\begin{array}{c}\text { Proportion } \\
\text { Covered by } \\
\text { FLSA Overtime } \\
\text { Pay Provisions }\end{array}$} & \multicolumn{2}{|c|}{$\begin{array}{c}\text { Proportion } \\
\text { Working } \\
\text { Overtime }\end{array}$} & \multicolumn{2}{|c|}{$\begin{array}{c}\text { Average Weekly } \\
\text { Overtime Hours } \\
\text { for Overtime } \\
\text { Workers }\end{array}$} & \multicolumn{2}{|c|}{$\begin{array}{l}\text { Average Weekly } \\
\text { Overtime Hours } \\
\text { for All Workers }\end{array}$} & \multicolumn{2}{|c|}{$\begin{array}{l}\text { CPS Sample } \\
\text { Size }\end{array}$} \\
\hline & 1970 & 1989 & 1970 & 1989 & 1970 & 1989 & 1970 & 1989 & 1970 & 1989 \\
\hline Agriculture & 0.00 & 0.00 & 0.48 & 0.43 & 20.7 & 20.4 & 9.9 & 8.8 & 813 & 986 \\
\hline Mining & 0.97 & 0.98 & 0.41 & 0.41 & 14.7 & 16.2 & 6.0 & 6.7 & 285 & 418 \\
\hline Construction & 0.98 & 0.99 & 0.25 & 0.28 & 10.7 & 11.7 & 2.6 & 3.3 & 2110 & 2645 \\
\hline Manufacturing & 0.96 & 0.98 & 0.26 & 0.33 & 10.7 & 10.9 & 2.8 & 3.6 & 11613 & 8524 \\
\hline $\begin{array}{l}\text { Transportation and } \\
\text { Public Utilities }\end{array}$ & 0.57 & 0.64 & 0.30 & 0.34 & 12.8 & 14.3 & 3.9 & 4.9 & 2583 & 2689 \\
\hline Wholesale Trade & 0.91 & 0.94 & 0.28 & 0.34 & 10.8 & 11.9 & 3.0 & 4.1 & 996 & 1151 \\
\hline Retail Trade & 0.44 & 0.82 & 0.24 & 0.16 & 11.4 & 11.2 & 2.7 & 1.8 & 5746 & 7271 \\
\hline $\begin{array}{l}\text { Finance, } \\
\text { Insurance, and } \\
\text { Real Estate }\end{array}$ & 0.94 & 0.95 & 0.10 & 0.15 & 10.2 & 9.9 & 1.0 & 1.5 & 1455 & 1857 \\
\hline $\begin{array}{l}\text { Services (except } \\
\text { domestic service) }\end{array}$ & 0.58 & 0.77 & 0.17 & 0.18 & 11.0 & 11.9 & 1.9 & 2.1 & 4527 & 7842 \\
\hline Domestic Service & 0.00 & 0.60 & 0.15 & 0.14 & 16.8 & 19.6 & 2.5 & 2.8 & 1151 & 594 \\
\hline Government & 0.40 & 0.91 & 0.16 & 0.18 & 14.3 & 13.1 & 2.3 & 2.3 & 4961 & 5224 \\
\hline All Industries & 0.66 & 0.84 & 0.23 & 0.24 & 12.0 & 12.3 & 2.8 & 2.9 & 36240 & 39201 \\
\hline
\end{tabular}

Note: All data pertain to nonsupervisory civilian workers excluding outside salesworkers. The estimates of coverage under FLSA overtime pay provisions are from the annual reports entitled Minimum Wage and Maximum Hours Standards Under the Fair Labor Standards Act submitted to Congress by the U.S. Department of Labor. All other data are computed from the May Current Population Survey (CPS) tapes. Overtime hours are defined as weekly hours of work in excess of 40 . 
Table 2

FLSA Overtime Pay Coverage and Overtime Hours, Summary Statistics, by Industry

\begin{tabular}{|c|c|c|c|c|c|c|c|c|}
\hline \multirow[b]{2}{*}{ Industry } & \multicolumn{2}{|c|}{$\begin{array}{c}\text { Proportion } \\
\text { Covered by FLSA } \\
\text { Overtime Pay } \\
\text { Provisions }\end{array}$} & \multicolumn{2}{|c|}{$\begin{array}{c}\text { Proportion } \\
\text { Working } \\
\text { Overtime }\end{array}$} & \multicolumn{2}{|c|}{$\begin{array}{c}\text { Average Weekly } \\
\text { Overtime Hours } \\
\text { for Overtime } \\
\text { Workers }\end{array}$} & \multicolumn{2}{|c|}{$\begin{array}{l}\text { Average Weekly } \\
\text { Overtime Hours } \\
\text { for All Workers }\end{array}$} \\
\hline & Mean & Std. Dev. & Mean & Std. Dev. & Mean & Std. Dev. & Mean & Std. Dev. \\
\hline Agriculture & 0.000 & 0.000 & 0.450 & 0.028 & 20.21 & 1.01 & 9.11 & 0.81 \\
\hline Mining & 0.982 & 0.006 & 0.417 & 0.039 & 16.25 & 1.57 & 6.78 & 0.90 \\
\hline Construction & 0.986 & 0.001 & 0.237 & 0.028 & 11.75 & 0.54 & 2.80 & 0.43 \\
\hline Manufacturing & 0.977 & 0.011 & 0.276 & 0.035 & 10.51 & 0.27 & 2.90 & 0.42 \\
\hline $\begin{array}{l}\text { Transportation and } \\
\text { Public Utilities }\end{array}$ & 0.617 & 0.028 & $0 . .299$ & 0.028 & 13.84 & 0.54 & 4.13 & 0.47 \\
\hline Wholesale Trade & 0.938 & 0.017 & 0.298 & 0.030 & 11.07 & 0.63 & 3.30 & 0.41 \\
\hline Retail Trade & 0.665 & 0.149 & 0.190 & 0.028 & 11.17 & 0.30 & 2.12 & 0.32 \\
\hline $\begin{array}{l}\text { Finance, } \\
\text { Insurance, and } \\
\text { Real Estate }\end{array}$ & 0.951 & 0.004 & 0.124 & 0.021 & 9.26 & 0.73 & 1.15 & 0.22 \\
\hline $\begin{array}{l}\text { Services (except } \\
\text { domestic service) }\end{array}$ & 0.713 & 0.082 & 0.162 & 0.012 & 11.62 & 0.45 & 1.88 & 0.19 \\
\hline Domestic Service & 0.479 & 0.247 & 0.121 & 0.019 & 18.99 & 2.68 & 2.30 & 0.47 \\
\hline Government & 0.518 & 0.302 & 0.154 & 0.012 & 13.43 & 0.72 & 2.06 & 0.23 \\
\hline All Industries & 0.758 & 0.064 & 0.220 & 0.018 & 12.07 & 0.16 & 2.66 & 0.23 \\
\hline
\end{tabular}

Note: The summary statistics reported here pertain to annual observations from 1970-1989 for each industry and for all industries combined. See the note to Table 1 for further details about the data. 
Table 3

\section{Determinants of Work Schedules and Average Weekly Overtime Hours Weighted Least Squares Estimates}

\begin{tabular}{|c|c|c|c|c|}
\hline \multirow[b]{2}{*}{ Independent Variable } & \multicolumn{4}{|c|}{ Dependent Variable } \\
\hline & $\begin{array}{l}\text { Proportion } \\
\text { Part Time }\end{array}$ & $\begin{array}{l}\text { Proportion } \\
\text { Full Time }\end{array}$ & $\begin{array}{c}\text { Proportion } \\
\text { Overtime }\end{array}$ & $\begin{array}{c}\text { Log of Weekly } \\
\text { Overtime } \\
\text { Hours Per } \\
\text { Worker }\end{array}$ \\
\hline Overtime Pay Coverage & $\begin{array}{c}0.037 \\
(0.009)\end{array}$ & $\begin{array}{l}-0.012 \\
(0.009)\end{array}$ & $\begin{array}{l}-0.025 \\
(0.009)\end{array}$ & $\begin{array}{l}-0.117 \\
(0.049)\end{array}$ \\
\hline Proportion Aged 16-29 & $\begin{array}{c}0.120 \\
(0.090)\end{array}$ & $\begin{array}{c}0.061 \\
(0.091)\end{array}$ & $\begin{array}{l}-0.182 \\
(0.096)\end{array}$ & $\begin{array}{l}-0.861 \\
(0.492)\end{array}$ \\
\hline Proportion Aged 50 \& Above & $\begin{array}{l}-0.059 \\
(0.147)\end{array}$ & $\begin{array}{c}0.112 \\
(0.149)\end{array}$ & $\begin{array}{l}-0.053 \\
(0.157)\end{array}$ & $\begin{array}{l}-0.091 \\
(0.804)\end{array}$ \\
\hline Proportion Female & $\begin{array}{c}0.149 \\
(0.111)\end{array}$ & $\begin{array}{l}-0.317 \\
(0.113)\end{array}$ & $\begin{array}{c}0.168 \\
(0.119)\end{array}$ & $\begin{array}{l}-0.009 \\
(0.609)\end{array}$ \\
\hline Proportion Nonwhite & $\begin{array}{c}0.029 \\
(0.097)\end{array}$ & $\begin{array}{l}-0.097 \\
(0.098)\end{array}$ & $\begin{array}{c}0.068 \\
(0.104)\end{array}$ & $\begin{array}{c}0.383 \\
(0.532)\end{array}$ \\
\hline Proportion Married & $\begin{array}{l}-0.057 \\
(0.101)\end{array}$ & $\begin{array}{c}0.263 \\
(0.102)\end{array}$ & $\begin{array}{l}-0.206 \\
(0.108)\end{array}$ & $\begin{array}{l}-0.791 \\
(0.555)\end{array}$ \\
\hline Average Years of Education & $\begin{array}{l}-0.048 \\
(0.014)\end{array}$ & $\begin{array}{l}-0.008 \\
(0.014)\end{array}$ & $\begin{array}{c}0.056 \\
(0.015)\end{array}$ & $\begin{array}{c}0.336 \\
(0.078)\end{array}$ \\
\hline Proportion Blue Collar & $\begin{array}{l}-0.336 \\
(0.093)\end{array}$ & $\begin{array}{l}-0.420 \\
(0.094)\end{array}$ & $\begin{array}{c}0.756 \\
(0.010)\end{array}$ & $\begin{array}{c}2.913 \\
(0.511)\end{array}$ \\
\hline Proportion Living in Midwest & $\begin{array}{l}-0.078 \\
(0.137)\end{array}$ & $\begin{array}{l}-0.151 \\
(0.139)\end{array}$ & $\begin{array}{c}0.229 \\
(0.146)\end{array}$ & $\begin{array}{c}0.526 \\
(0.750)\end{array}$ \\
\hline Proportion Living in South & $\begin{array}{c}0.095 \\
(0.120)\end{array}$ & $\begin{array}{l}-0.301 \\
(0.121)\end{array}$ & $\begin{array}{c}0.207 \\
(0.128)\end{array}$ & $\begin{array}{c}1.243 \\
(0.657)\end{array}$ \\
\hline Proportion Living in West & $\begin{array}{l}-0.340 \\
(0.134)\end{array}$ & $\begin{array}{c}0.127 \\
(0.136)\end{array}$ & $\begin{array}{c}0.212 \\
(0.143)\end{array}$ & $\begin{array}{c}1.809 \\
(0.735)\end{array}$ \\
\hline $\mathrm{R}^{2}$ & 0.992 & 0.986 & 0.967 & 0.966 \\
\hline
\end{tabular}

Note: Standard errors are in parentheses. Sample size is 220. All regressions include industry and year fixed effects. Part-time workers are those with weekly hours less than 40, full-time workers have workweeks of exactly 40 hours, and overtime hours are weekly hours in excess of 40. 
Table 4

\section{The Effects of FLSA Overtime Pay Coverage in Alternative Specifications Weighted Least Squares Estimates}

\begin{tabular}{|c|c|c|c|c|}
\hline \multirow[b]{2}{*}{ Specification/Independent Variable } & \multicolumn{4}{|c|}{ Dependent Variable } \\
\hline & $\begin{array}{l}\text { Proportion } \\
\text { Part Time } \\
\end{array}$ & $\begin{array}{l}\text { Proportion } \\
\text { Full Time } \\
\end{array}$ & $\begin{array}{c}\text { Proportion } \\
\text { Overtime }\end{array}$ & $\begin{array}{c}\text { Log of Weekly } \\
\text { Overtime Hours } \\
\text { Per Worker }\end{array}$ \\
\hline $\begin{array}{l}\text { (1) Separate Government Effect: } \\
\text { Overtime Pay Coverage }\end{array}$ & $\begin{array}{c}0.151 \\
(0.019)\end{array}$ & $\begin{array}{l}-0.065 \\
(0.021)\end{array}$ & $\begin{array}{l}-0.085 \\
(0.022)\end{array}$ & $\begin{array}{l}-0.428 \\
(0.114)\end{array}$ \\
\hline $\begin{array}{l}\text { Overtime Pay Coverage } \\
\times \text { Government }\end{array}$ & $\begin{array}{l}-0.140 \\
(0.021)\end{array}$ & $\begin{array}{c}0.066 \\
(0.024)\end{array}$ & $\begin{array}{c}0.074 \\
(0.025)\end{array}$ & $\begin{array}{c}0.384 \\
(0.127)\end{array}$ \\
\hline $\begin{array}{l}\text { (2) Add Linear Time Trends to (1): } \\
\text { Overtime Pay Coverage }\end{array}$ & $\begin{array}{c}0.058 \\
(0.024)\end{array}$ & $\begin{array}{l}-0.058 \\
(0.028)\end{array}$ & $\begin{array}{l}-0.0004 \\
(0.0295)\end{array}$ & $\begin{array}{l}-0.032 \\
(0.150)\end{array}$ \\
\hline $\begin{array}{l}\text { Overtime Pay Coverage } \\
\times \text { Government }\end{array}$ & $\begin{array}{l}-0.053 \\
(0.026)\end{array}$ & $\begin{array}{c}0.065 \\
(0.031)\end{array}$ & $\begin{array}{l}-0.012 \\
(0.033)\end{array}$ & $\begin{array}{c}0.016 \\
(0.165)\end{array}$ \\
\hline $\begin{array}{l}\text { Industry Time Trends: } \\
\text { Transportation }\end{array}$ & $\begin{array}{c}0.0025 \\
(0.0007)\end{array}$ & $\begin{array}{l}-0.0029 \\
(0.0008)\end{array}$ & $\begin{array}{c}0.0004 \\
(0.0008)\end{array}$ & $\begin{array}{c}0.0044 \\
(0.0042)\end{array}$ \\
\hline Retail Trade & $\begin{array}{c}0.0050 \\
(0.0010)\end{array}$ & $\begin{array}{c}0.0004 \\
(0.0012)\end{array}$ & $\begin{array}{l}-0.0054 \\
(0.0012)\end{array}$ & $\begin{array}{l}-0.0267 \\
(0.0061)\end{array}$ \\
\hline Services & $\begin{array}{c}0.0022 \\
(0.0006)\end{array}$ & $\begin{array}{l}-0.0005 \\
(0.0007)\end{array}$ & $\begin{array}{l}-0.0016 \\
(0.0007)\end{array}$ & $\begin{array}{l}-0.0084 \\
(0.0037)\end{array}$ \\
\hline Domestic Service & $\begin{array}{c}0.0027 \\
(0.0016)\end{array}$ & $\begin{array}{c}0.0012 \\
(0.0019)\end{array}$ & $\begin{array}{l}-0.0038 \\
(0.0020)\end{array}$ & $\begin{array}{l}-0.0209 \\
(0.0103)\end{array}$ \\
\hline Government & $\begin{array}{c}0.0022 \\
(0.0006)\end{array}$ & $\begin{array}{l}-0.0021 \\
(0.0007)\end{array}$ & $\begin{array}{l}-0.0001 \\
(0.0007)\end{array}$ & $\begin{array}{l}-0.0064 \\
(0.0037)\end{array}$ \\
\hline
\end{tabular}

(3) Add Quadratic Time Trends to (1):

$\begin{array}{lcccc}\text { Overtime Pay Coverage } & .028 & -.021 & -.007 & .167 \\ & (.032) & (.037) & (.040) & (.202) \\ \text { Overtime Pay Coverage } & & & & \\ \quad \times \text { Government } & -.019 & .018 & .0003 & -.213 \\ & (.034) & (.039) & (.0416) & (.212)\end{array}$

Note: Standard errors are in parentheses. Sample size is 220. All regressions control for the other independent variables in Table 3, including industry and year fixed effects. For specification (3), the coefficients of the quadratic industry time trends are not reported. Part-time workers are those with weekly hours less than 40, full-time workers have workweeks of exactly 40 hours, and overtime hours are weekly hours in excess of 40. 
Table 5

The Effects of FLSA Overtime Pay Coverage in First-Differenced Regressions
Weighted Least Squares Estimates

\begin{tabular}{|c|c|c|c|c|c|}
\hline \multirow[b]{2}{*}{$\begin{array}{l}\text { Specification/ } \\
\text { Length of Differences }\end{array}$} & \multicolumn{4}{|c|}{ Dependent Variable } & \multirow[b]{2}{*}{$\begin{array}{c}\text { Sample } \\
\text { Size }\end{array}$} \\
\hline & $\begin{array}{l}\text { Proportion } \\
\text { Part Time }\end{array}$ & $\begin{array}{l}\text { Proportion } \\
\text { Full Time }\end{array}$ & $\begin{array}{c}\text { Proportion } \\
\text { Overtime }\end{array}$ & $\begin{array}{c}\text { Log of Weekly } \\
\text { Overtime Hours } \\
\text { Per Worker }\end{array}$ & \\
\hline $\begin{array}{l}\text { Excluding Industry Fixed Eff } \\
\text { Two-Year Differences }\end{array}$ & $\begin{array}{l}.056 \\
(.025)\end{array}$ & $\begin{array}{l}-.002 \\
(.031)\end{array}$ & $\begin{array}{l}-.054 \\
(.035)\end{array}$ & $\begin{array}{l}-.132 \\
(.160)\end{array}$ & 198 \\
\hline Four-Year Differences & $\begin{array}{c}.082 \\
(.021)\end{array}$ & $\begin{array}{l}-.038 \\
(.027)\end{array}$ & $\begin{array}{l}-.044 \\
(.028)\end{array}$ & $\begin{array}{l}-.094 \\
(.144)\end{array}$ & 176 \\
\hline Six-Year Differences & $\begin{array}{l}.116 \\
(.022)\end{array}$ & $\begin{array}{l}-.070 \\
(.026)\end{array}$ & $\begin{array}{l}-.046 \\
(.027)\end{array}$ & $\begin{array}{l}-.215 \\
(.135)\end{array}$ & 154 \\
\hline Eight-Year Differences & $\begin{array}{l}.131 \\
(.024)\end{array}$ & $\begin{array}{l}-.068 \\
(.025)\end{array}$ & $\begin{array}{l}-.063 \\
(.027)\end{array}$ & $\begin{array}{l}-.506 \\
(.137)\end{array}$ & 132 \\
\hline Ten-Year Differences & $\begin{array}{l}.163 \\
(.026)\end{array}$ & $\begin{array}{l}-.098 \\
(.027)\end{array}$ & $\begin{array}{l}-.066 \\
(.028)\end{array}$ & $\begin{array}{l}-.453 \\
(.154)\end{array}$ & 110 \\
\hline $\begin{array}{l}\text { Including Industry Fixed Effe } \\
\text { Two-Year Differences }\end{array}$ & $\begin{array}{l}.035 \\
(.027)\end{array}$ & $\begin{array}{l}-.010 \\
(.035)\end{array}$ & $\begin{array}{l}-.025 \\
(.038)\end{array}$ & $\begin{array}{l}.027 \\
(.174)\end{array}$ & 198 \\
\hline Four-Year Differences & $\begin{array}{l}.035 \\
(.023)\end{array}$ & $\begin{array}{l}-.035 \\
(.032)\end{array}$ & $\begin{array}{l}.00003 \\
(.033)\end{array}$ & $\begin{array}{l}.157 \\
(.164)\end{array}$ & 176 \\
\hline Six-Year Differences & $\begin{array}{l}.050 \\
(.024)\end{array}$ & $\begin{array}{l}-.086 \\
(.032)\end{array}$ & $\begin{array}{l}.036 \\
(.032)\end{array}$ & $\begin{array}{l}.171 \\
(.159)\end{array}$ & 154 \\
\hline Eight-Year Differences & $\begin{array}{l}.041 \\
(.026)\end{array}$ & $\begin{array}{l}-.058 \\
(.033)\end{array}$ & $\begin{array}{l}.017 \\
(.034)\end{array}$ & $\begin{array}{l}-.121 \\
(.164)\end{array}$ & 132 \\
\hline Ten-Year Differences & $\begin{array}{c}.059 \\
(.029)\end{array}$ & $\begin{array}{l}-.050 \\
(.036)\end{array}$ & $\begin{array}{l}-.009 \\
(.036)\end{array}$ & $\begin{array}{l}-.320 \\
(.188)\end{array}$ & 110 \\
\hline
\end{tabular}

Note: Standard errors are in parentheses. The entries in this table are the coefficients on FLSA overtime pay coverage from first-differenced regressions corresponding to specification (1) in Table 4. Not reported are the coefficients of the interaction term between overtime pay coverage and the government sector. All regressions include year fixed effects, and those in the bottom half of the table also include industry fixed effects. Part-time workers are those with weekly hours less than 40, full-time workers have workweeks of exactly 40 hours, and overtime hours are weekly hours in excess of 40. 
Table 6

$F$ Tests for the Joint Significance of Industry Fixed Effects in First-Differenced Regressions

\begin{tabular}{|c|c|c|c|c|}
\hline \multirow[b]{2}{*}{ Length of Differences } & \multicolumn{4}{|c|}{ Dependent Variable } \\
\hline & $\begin{array}{l}\text { Proportion } \\
\text { Part Time } \\
\end{array}$ & $\begin{array}{c}\text { Proportion } \\
\text { Full Time } \\
\end{array}$ & $\begin{array}{c}\text { Proportion } \\
\text { Overtime }\end{array}$ & $\begin{array}{c}\text { Log of Weekly } \\
\text { Overtime Hours } \\
\text { Per Worker }\end{array}$ \\
\hline Two-Year Differences & $\begin{array}{l}1.46 \\
(.157)\end{array}$ & $\begin{array}{l}.43 \\
(.932)\end{array}$ & $\begin{array}{c}.63 \\
(.789)\end{array}$ & $\begin{array}{c}.96 \\
(.482)\end{array}$ \\
\hline Four-Year Differences & $\begin{array}{l}3.27 \\
(.001)\end{array}$ & $\begin{array}{l}.49 \\
(.485)\end{array}$ & $\begin{array}{l}1.16 \\
(.325)\end{array}$ & $\begin{array}{l}1.71 \\
(.083)\end{array}$ \\
\hline Six-Year Differences & $\begin{array}{l}5.91 \\
(.000)\end{array}$ & $\begin{array}{l}1.58 \\
(.120)\end{array}$ & $\begin{array}{l}2.21 \\
(.022)\end{array}$ & $\begin{array}{l}2.96 \\
(.002)\end{array}$ \\
\hline Eight-Year Differences & $\begin{array}{l}6.54 \\
(.000)\end{array}$ & $\begin{array}{l}1.90 \\
(.054)\end{array}$ & $\begin{array}{l}2.50 \\
(.010)\end{array}$ & $\begin{array}{l}3.91 \\
(.000)\end{array}$ \\
\hline Ten-Year Differences & $\begin{array}{l}7.34 \\
(.000)\end{array}$ & $\begin{array}{l}2.29 \\
(.021)\end{array}$ & $\begin{array}{l}3.71 \\
(.000)\end{array}$ & $\begin{array}{l}4.20 \\
(.000)\end{array}$ \\
\hline
\end{tabular}

Note: The entries in this table are $F$ statistics for tests of the joint significance of the industry fixed effects in the firstdifferenced regressions reported in the bottom half of Table 5. Listed in parentheses are the associated probability values, which represent the smallest significance level at which the null hypothesis of no industry fixed effects can be rejected. Part-time workers are those with weekly hours less than 40, full-time workers have workweeks of exactly 40 hours, and overtime hours are weekly hours in excess of 40. 


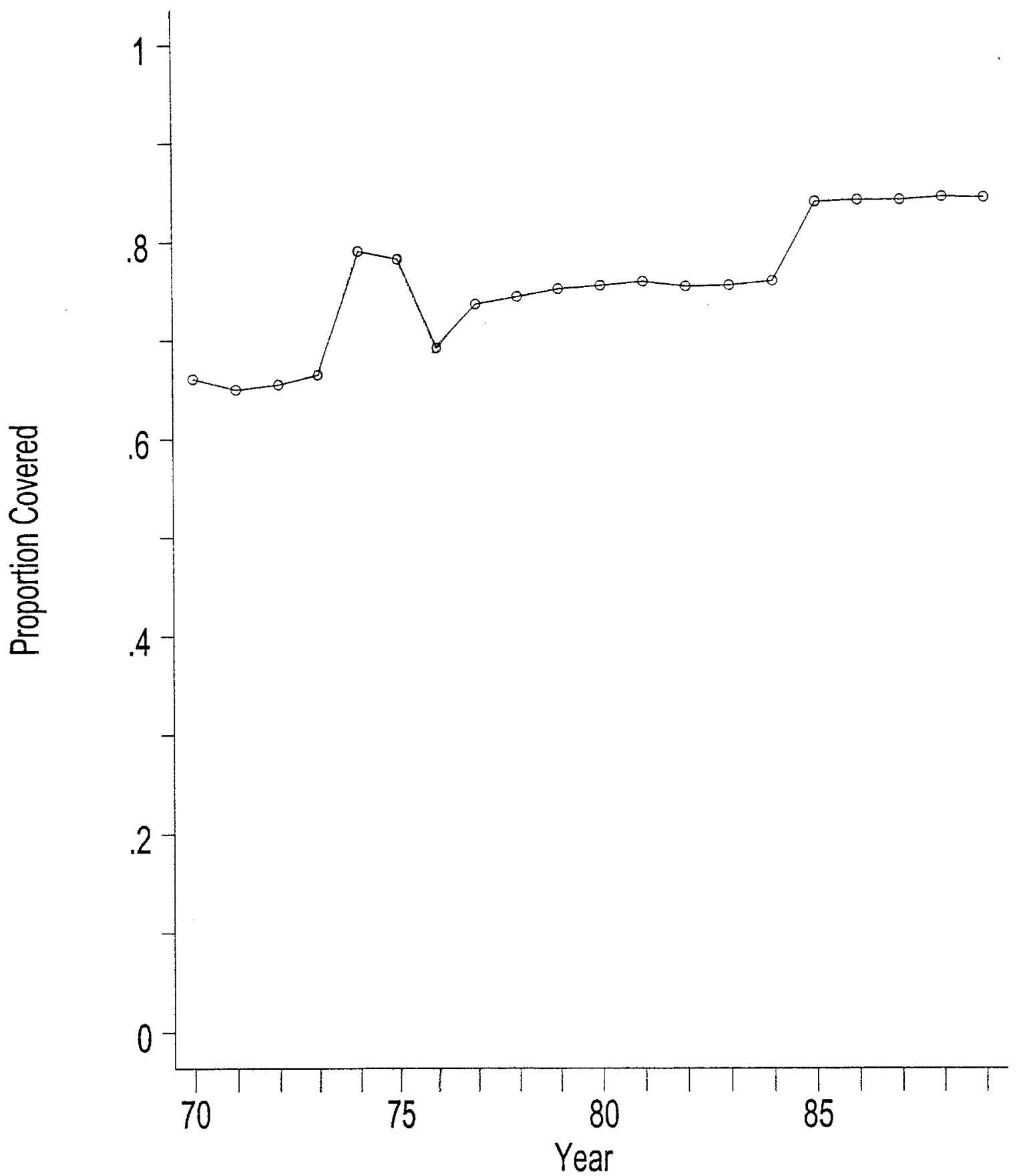

Figure 1. Coverage Under FLSA Overtime Pay Provisions 
- manufacturing $\quad$ retail trade
- government

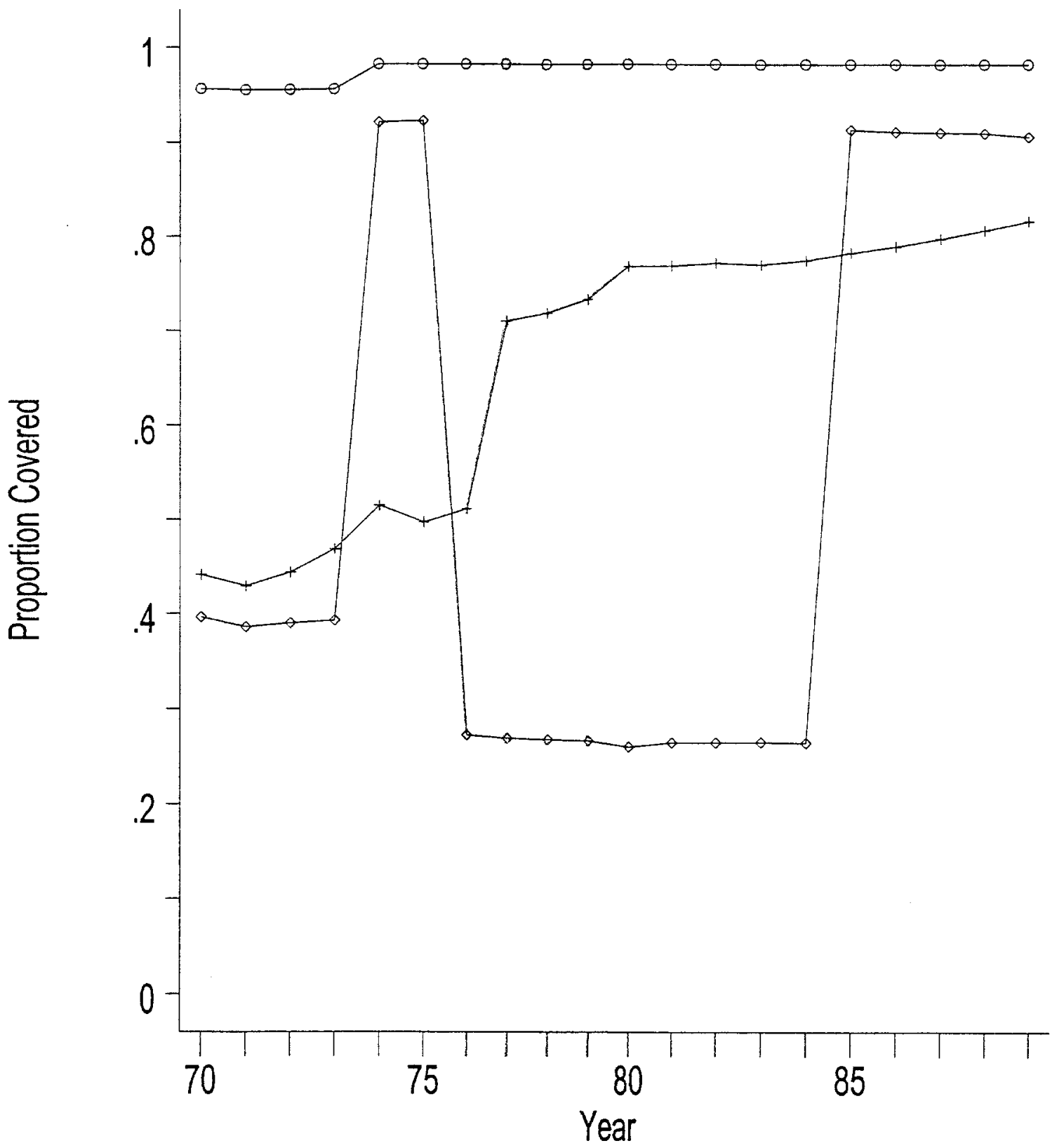

Figure 2. Overtime Pay Coverage for Selected Industries 
- FLSA Overtime Pay Coverage + Proportion Part Time

- Proportion Full Time

- Proportion Overtime

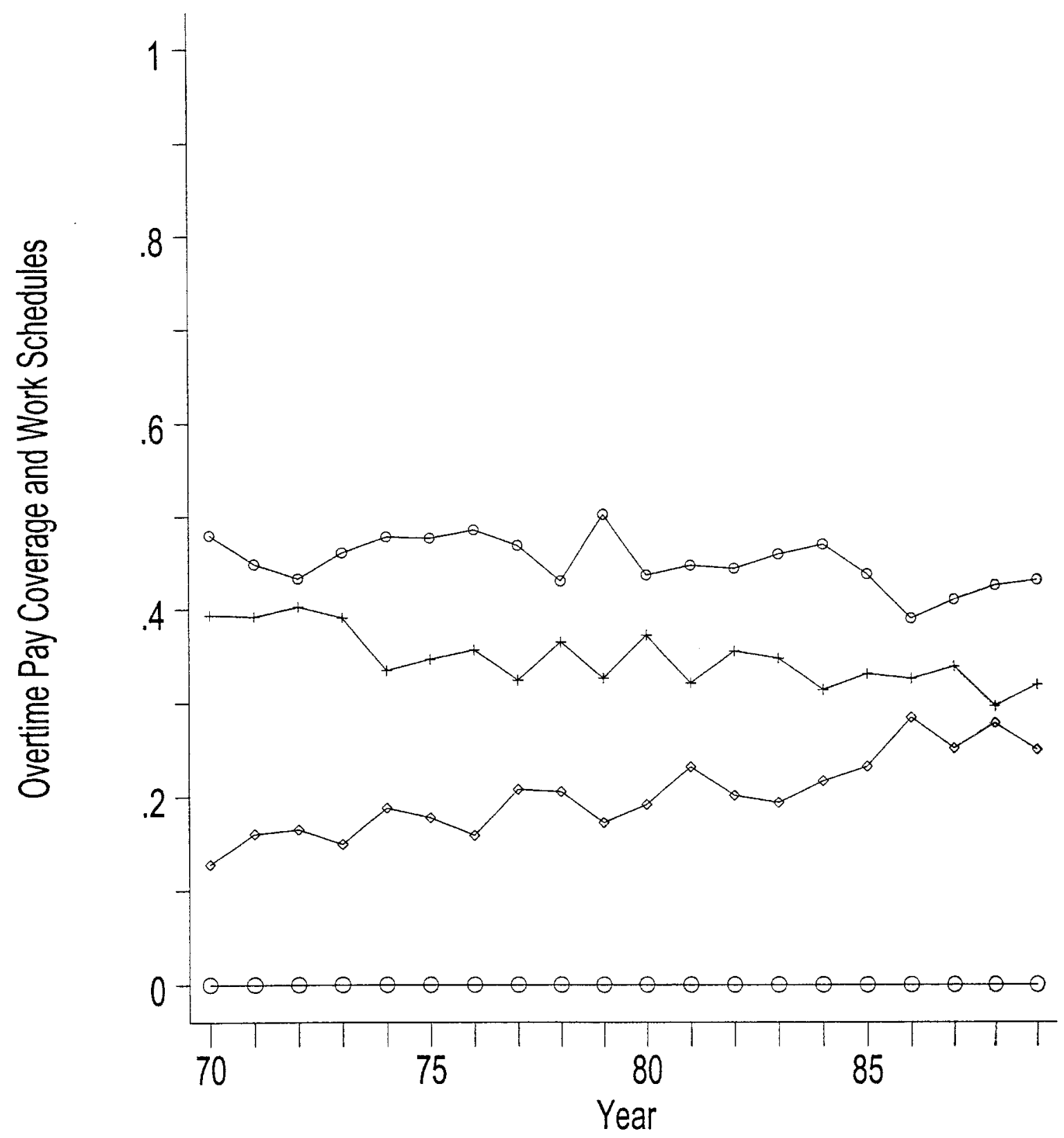

Figure 3. Agriculture 
- FLSA Overtime Pay Coverage + Proportion Part Time

- Proportion Full Time

- Proportion Overtime

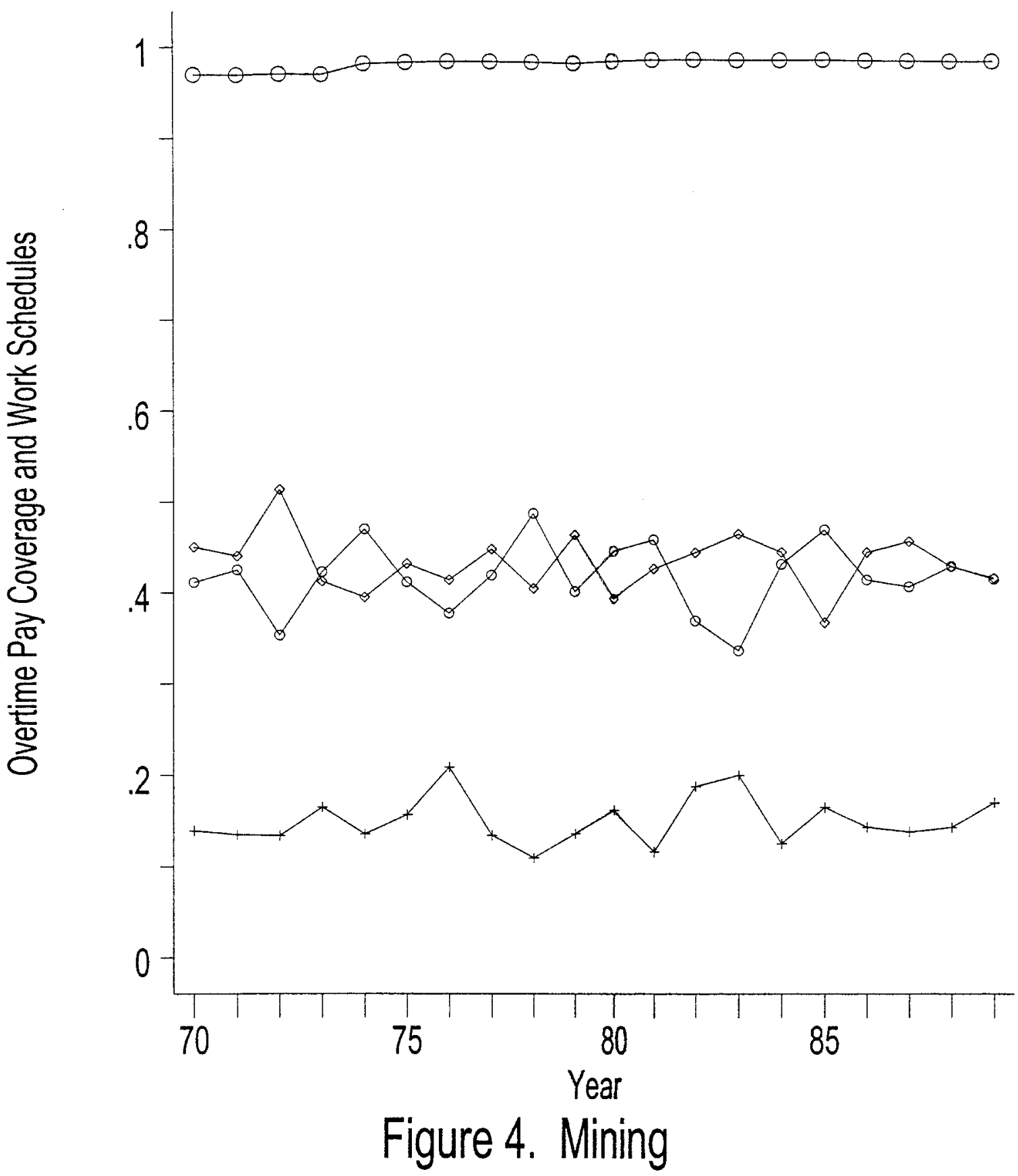


- FLSA Overtime Pay Coverage + Proportion Part Time

- Proportion Full Time

- Proportion Overtime

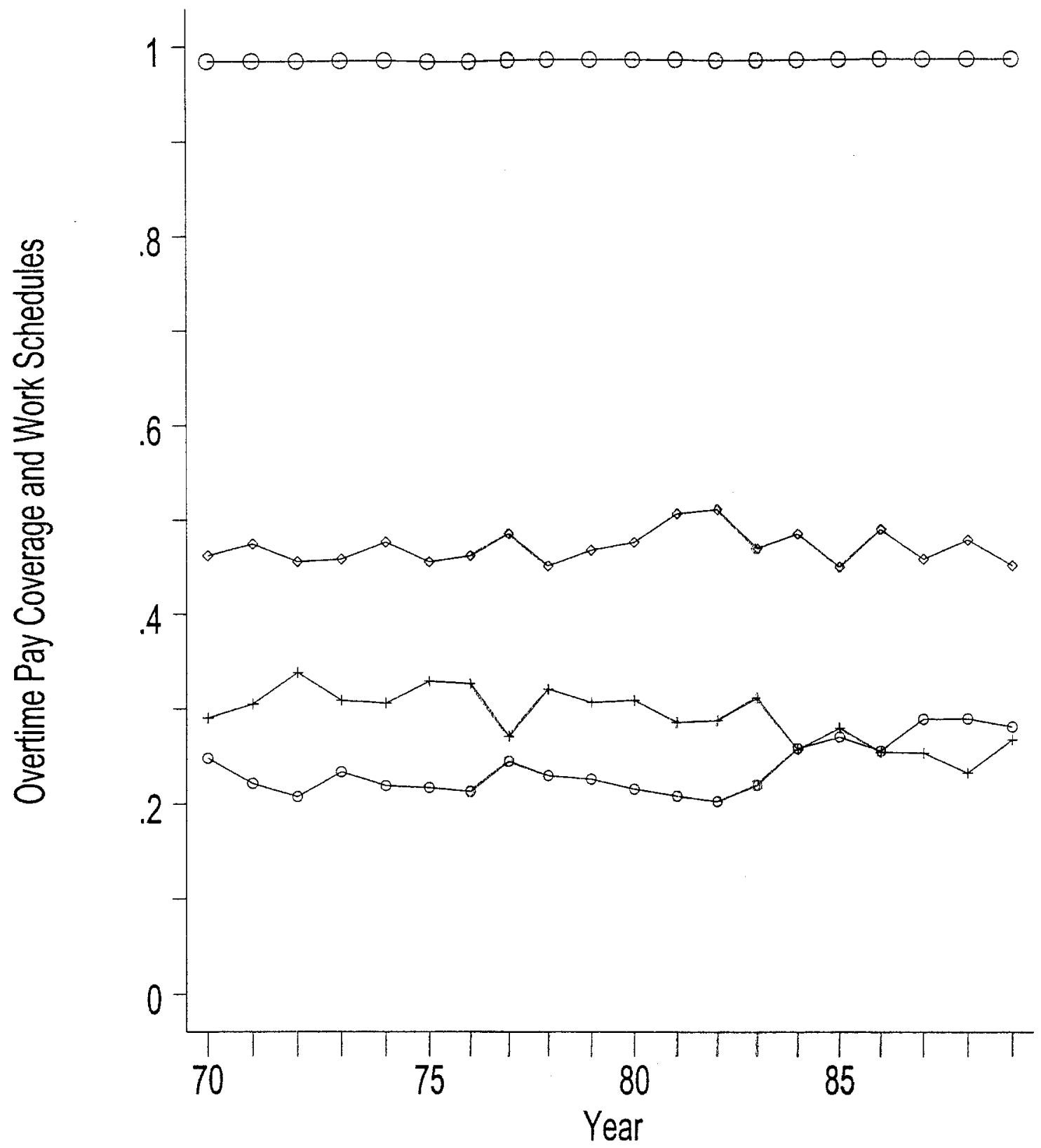

Figure 5. Construction 
- FLSA Overtime Pay Coverage + Proportion Part Time

- Proportion Full Time

- Proportion Overtime

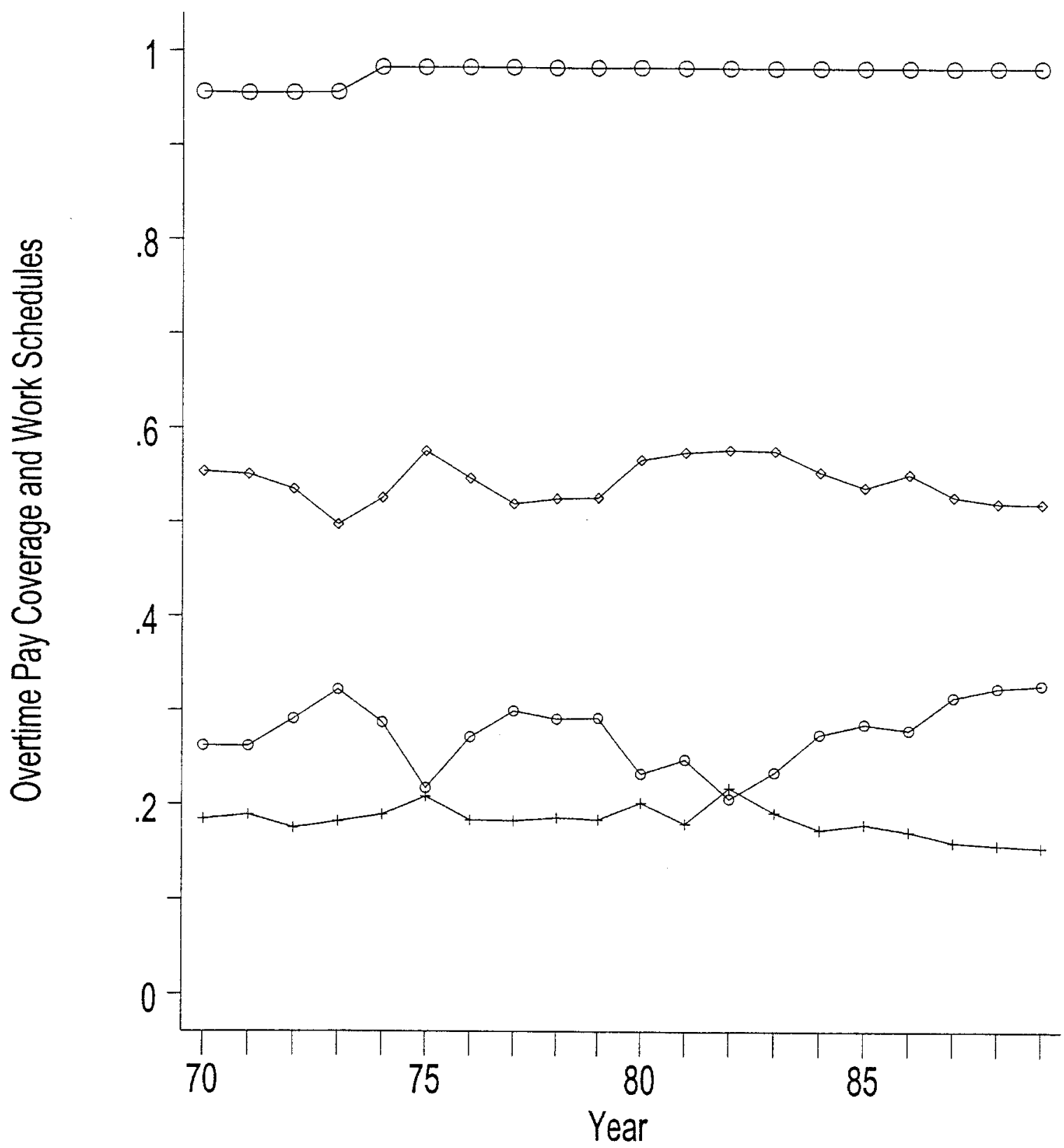

Figure 6. Manufacturing 
- FLSA Overtime Pay Coverage + Proportion Part Time

- Proportion Full Time

- Proportion Overtime

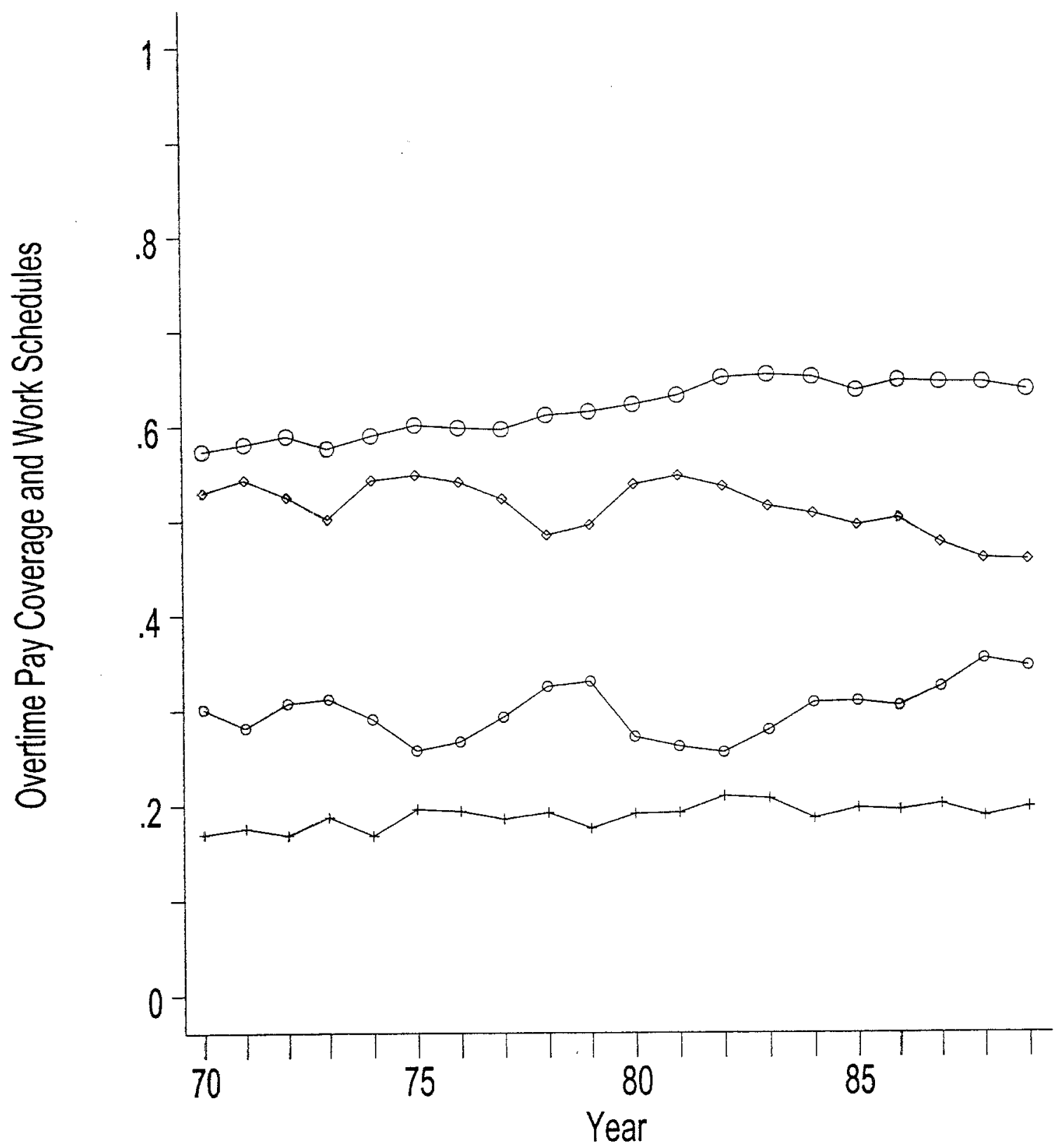

Figure 7. Transportation and Public Utilities 
o FLSA Overtime Pay Coverage + Proportion Part Time

- Proportion Full Time

- Proportion Overtime

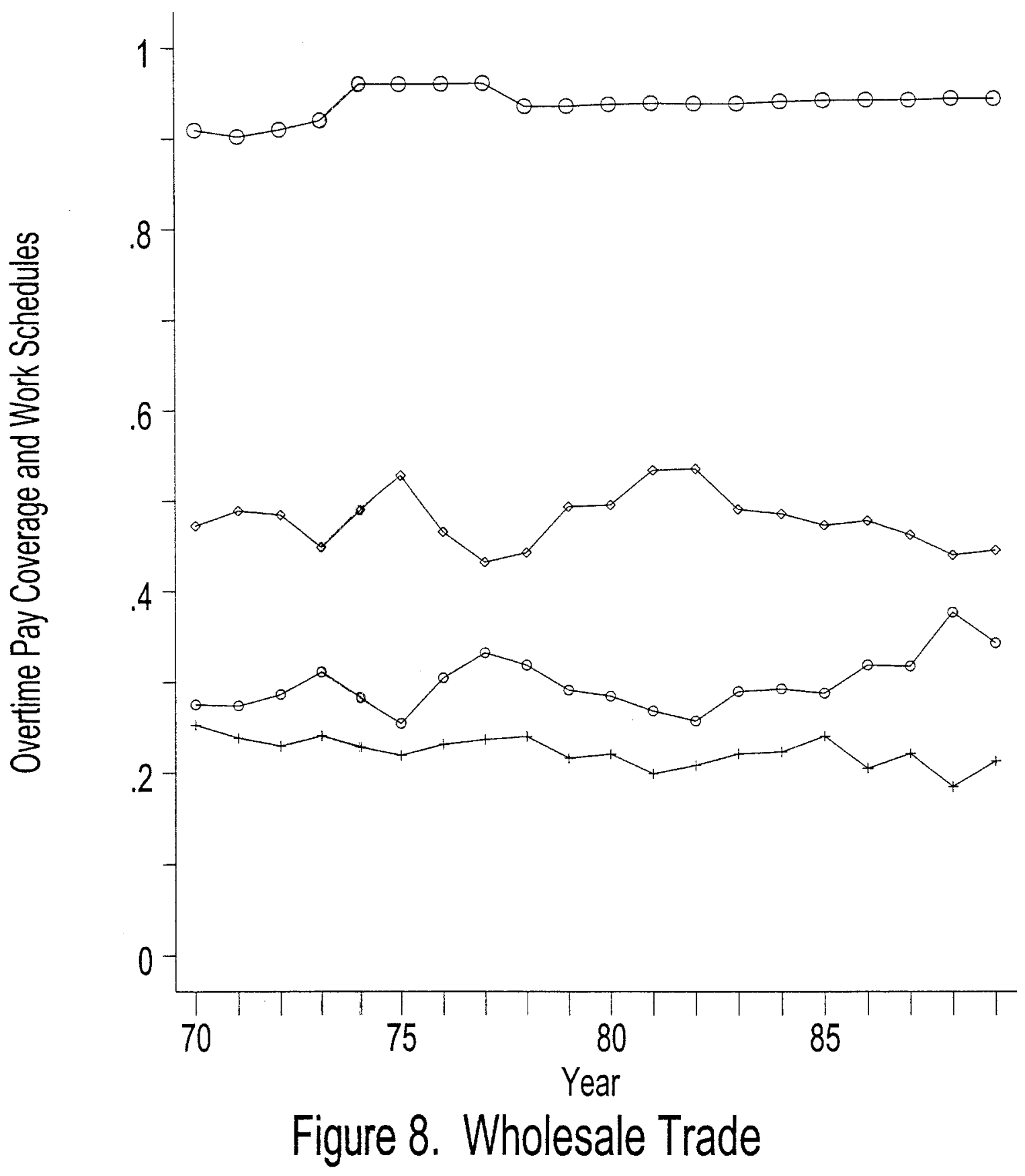


o FLSA Overtime Pay Coverage + Proportion Part Time

- Proportion Full Time

- Proportion Overtime

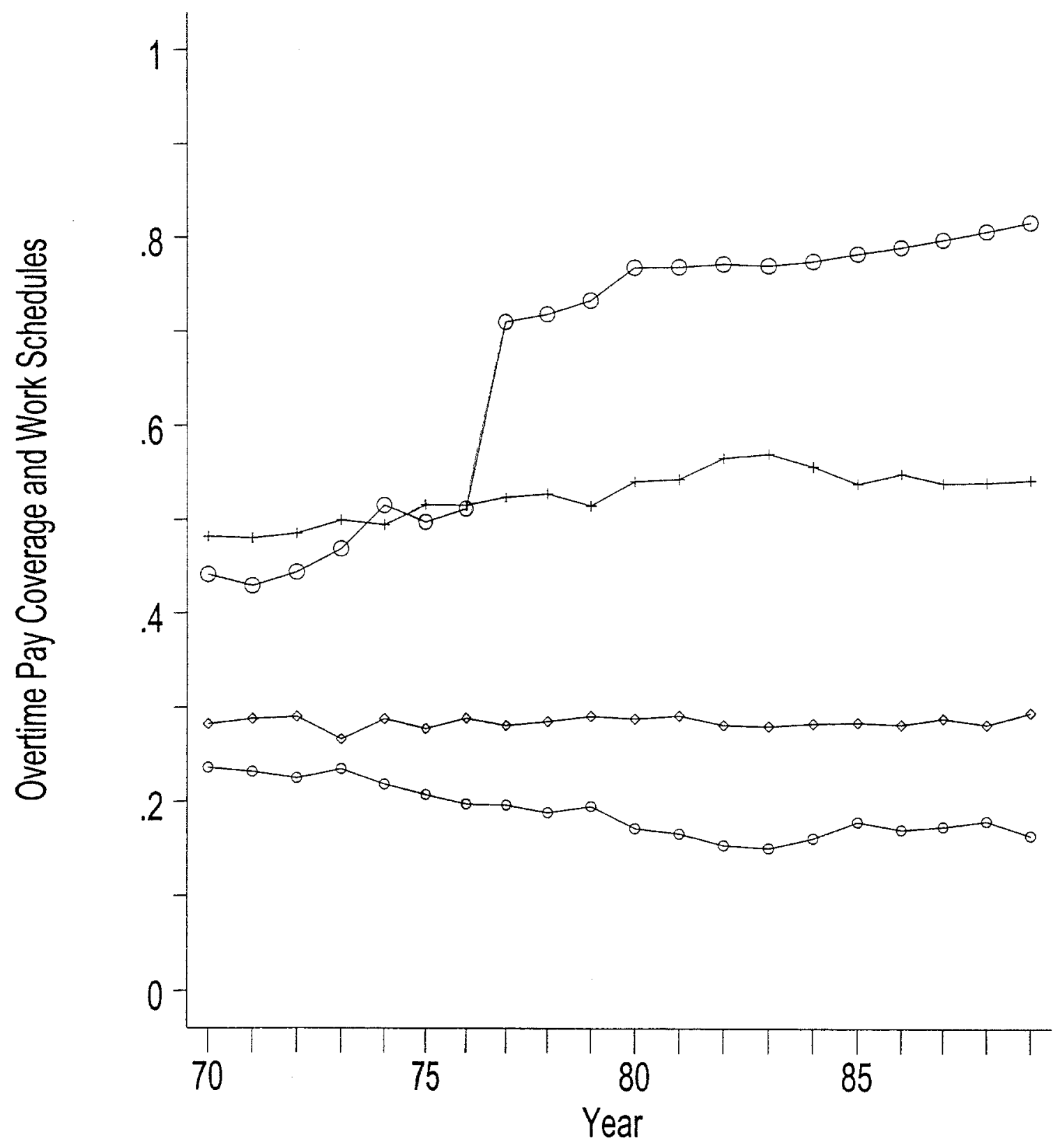

Figure 9. Retail Trade 
- FLSA Overtime Pay Coverage + Proportion Part Time

- Proportion Full Time

- Proportion Overtime

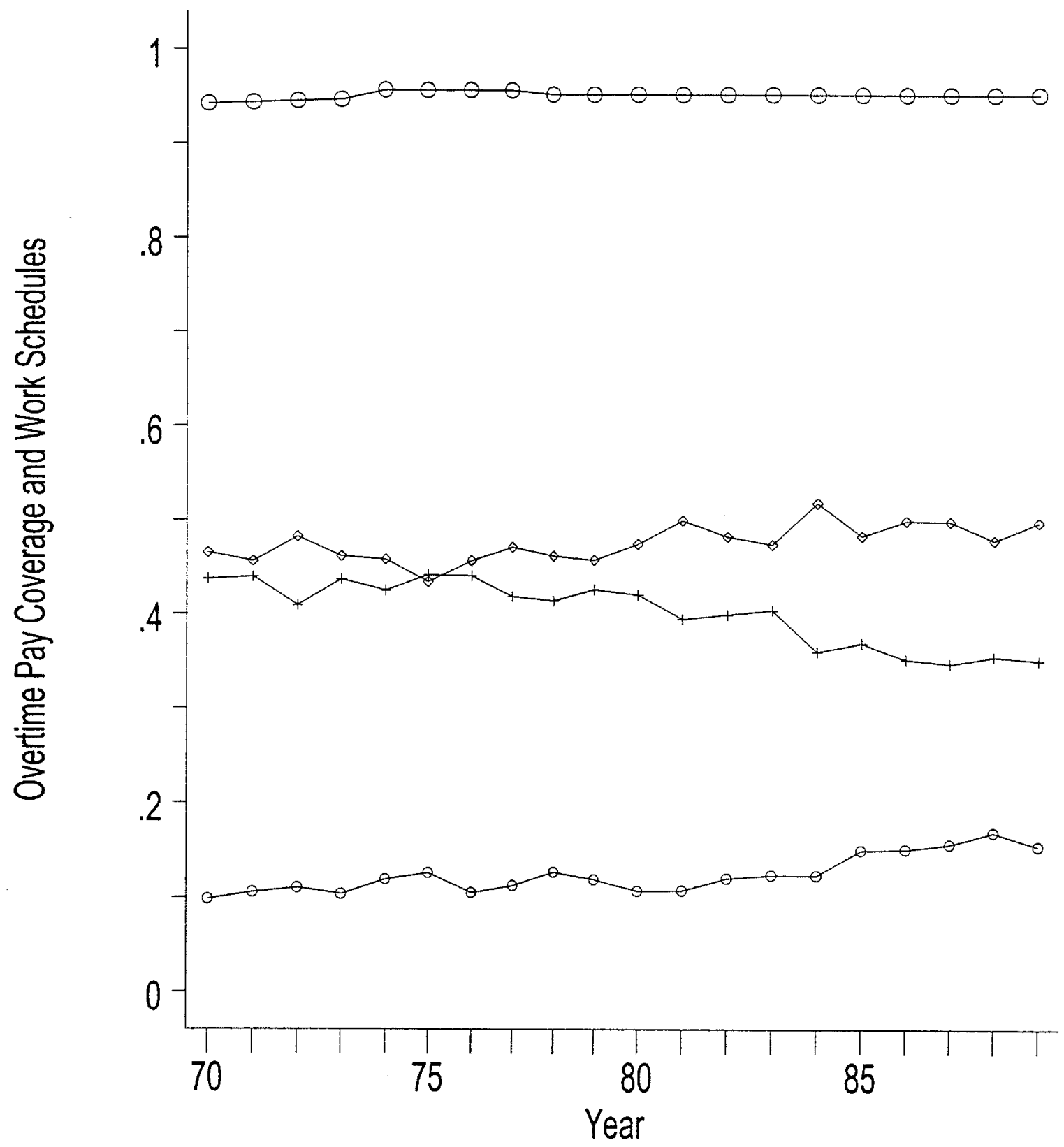

Figure 10. Finance, Insurance, and Real Estate 
- FLSA Overtime Pay Coverage + Proportion Part Time

- Proportion Full Time o Proportion Overtime

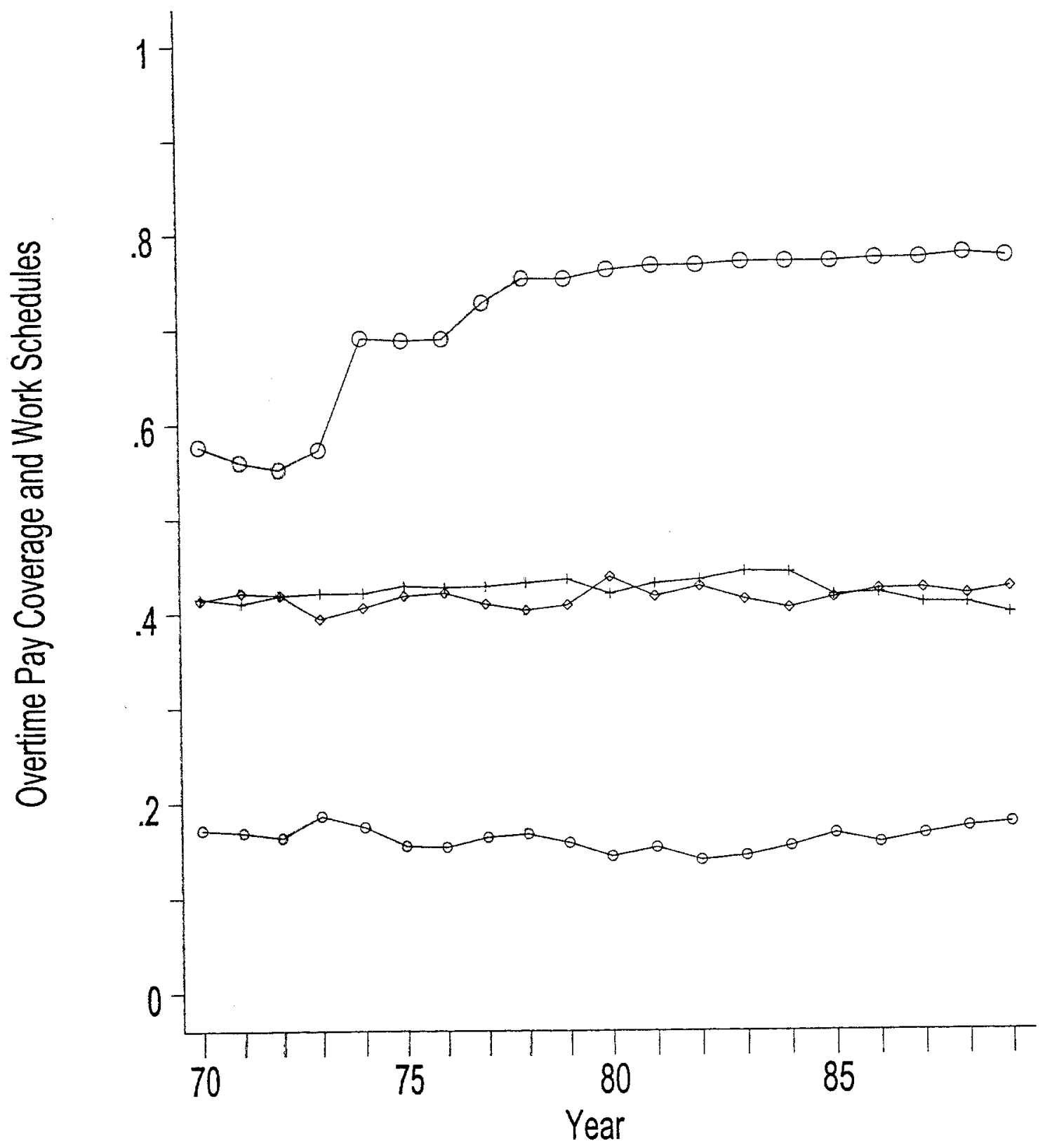

Figure 11. Services (Except Domestic Service) 
- FLSA Overtime Pay Coverage + Proportion Part Time

- Proportion Full Time o Proportion Overtime

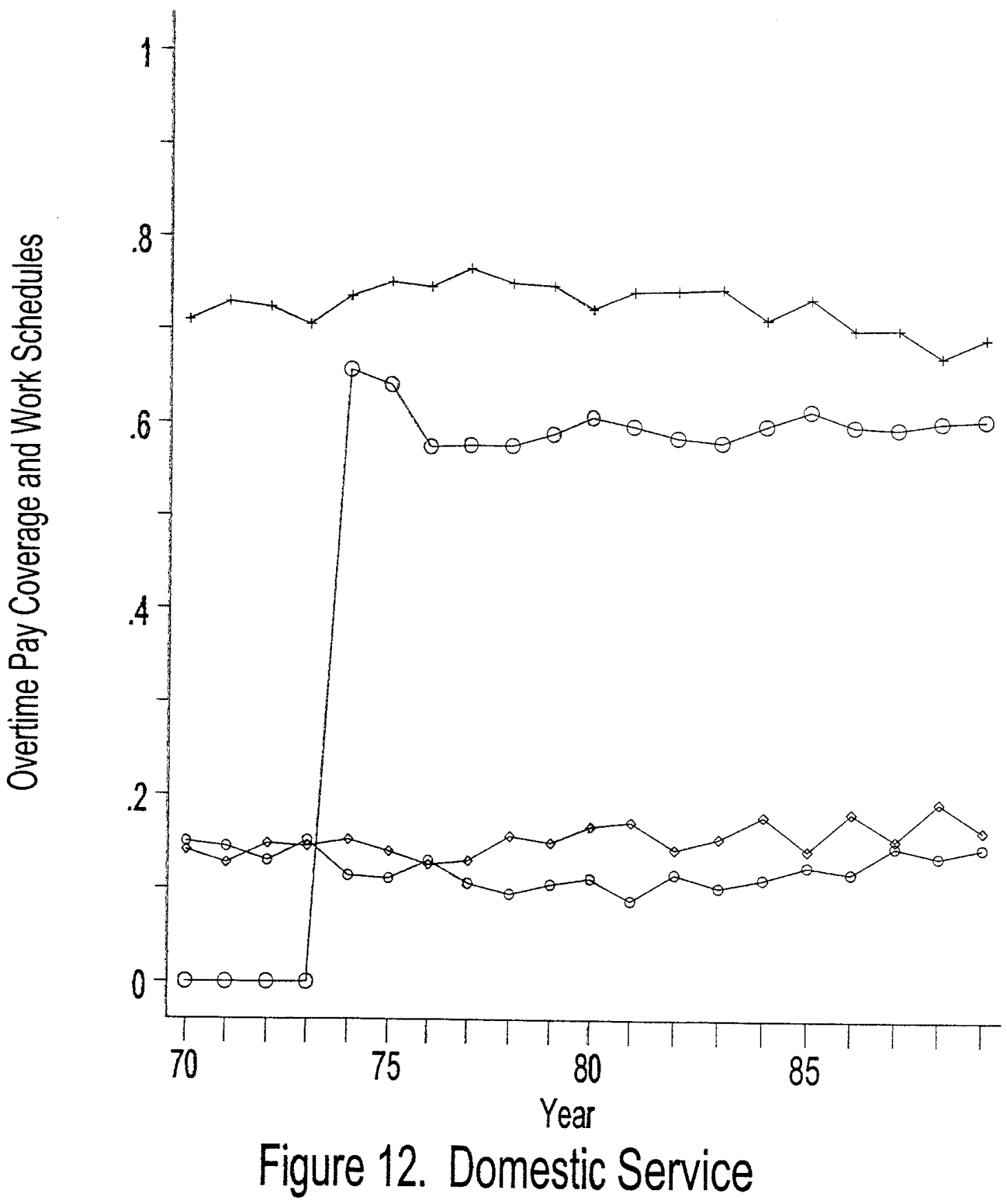


- FLSA Overtime Pay Coverage + Proportion Part Time

- Proportion Full Time

- Proportion Overtime

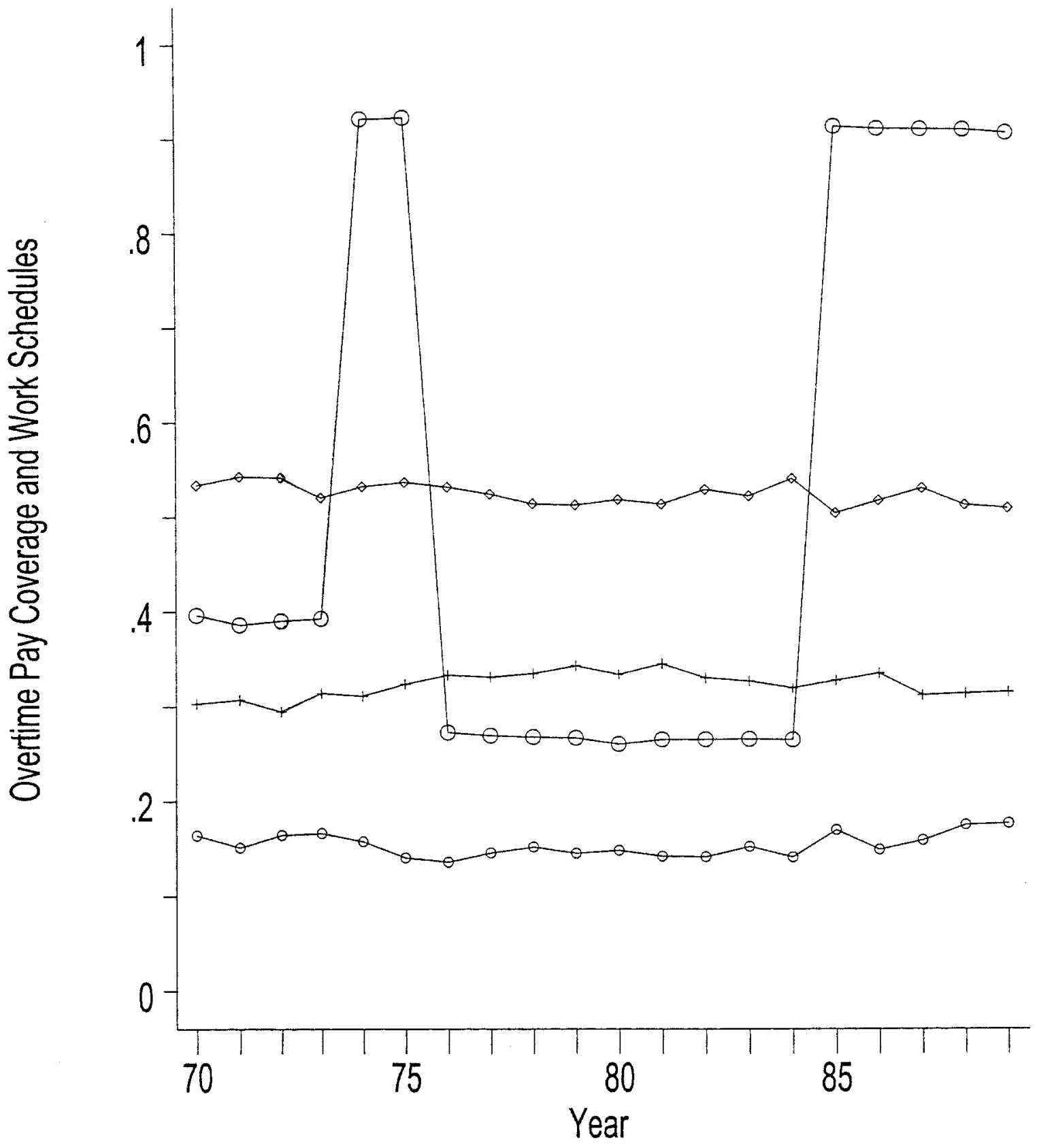

Figure 13. Government 


\section{IZA Discussion Papers}

\begin{tabular}{|c|c|c|c|c|}
\hline No. & Author(s) & Title & Area & Date \\
\hline 359 & M. Pflüger & $\begin{array}{l}\text { A Simple, Analytically Solvable Chamberlinian } \\
\text { Agglomeration Model }\end{array}$ & 2 & 09/01 \\
\hline 360 & $\begin{array}{l}\text { J. Hansen } \\
\text { M. Lofstrom }\end{array}$ & $\begin{array}{l}\text { The Dynamics of Immigrant Welfare and Labor } \\
\text { Market Behvior }\end{array}$ & $1 / 3$ & 09/01 \\
\hline 361 & $\begin{array}{l}\text { M. C. Berger } \\
\text { J. S. Earle } \\
\text { K. Z. Sabirianova }\end{array}$ & $\begin{array}{l}\text { Worker Training in a Restructuring Economy: } \\
\text { Evidence from the Russian Transition }\end{array}$ & 4 & 09/01 \\
\hline 362 & $\begin{array}{l}\text { J. Angrist } \\
\text { V. Lavy }\end{array}$ & $\begin{array}{l}\text { New Evidence on Classroom Computers and } \\
\text { Pupil Learning }\end{array}$ & 6 & 09/01 \\
\hline 363 & $\begin{array}{l}\text { H. Antecol } \\
\text { D. A. Cobb-Clark } \\
\text { S. J. Trejo }\end{array}$ & $\begin{array}{l}\text { Immigration Policy and the Skills of Immigrants } \\
\text { to Australia, Canada, and the United States }\end{array}$ & 2 & 09/01 \\
\hline 364 & $\begin{array}{l}\text { M. Jäntti } \\
\text { S. P. Jenkins }\end{array}$ & $\begin{array}{l}\text { Examining the Impact of Macro-Economic } \\
\text { Conditions on Income Inequality }\end{array}$ & 3 & 09/01 \\
\hline 365 & $\begin{array}{l}\text { H. S. Nielsen } \\
\text { M. Rosholm } \\
\text { N. Smith } \\
\text { L. Husted }\end{array}$ & $\begin{array}{l}\text { Qualifications, Discrimination, or Assimilation? } \\
\text { An Extended Framework for Analysing } \\
\text { Immigrant Wage Gaps }\end{array}$ & 1 & 09/01 \\
\hline 366 & M. C. Regets & $\begin{array}{l}\text { Research and Policy Issues in High-Skilled } \\
\text { International Migration: A Perspective with Data } \\
\text { from the United States }\end{array}$ & $1 / 5$ & 09/01 \\
\hline 367 & C. Dustmann & $\begin{array}{l}\text { Parental Background, Primary to Secondary } \\
\text { School Transitions, and Wages }\end{array}$ & 5 & 09/01 \\
\hline 368 & J. Angrist & $\begin{array}{l}\text { How Do Sex Ratios Affect Marriage and Labor } \\
\text { Markets? Evidence from America's Second } \\
\text { Generation }\end{array}$ & 5 & 09/01 \\
\hline 369 & A. S. Kalwij & $\begin{array}{l}\text { Individuals' Unemployment Durations over the } \\
\text { Business Cycle }\end{array}$ & 3 & 09/01 \\
\hline 370 & A. S. Kalwij & $\begin{array}{l}\text { Individuals' Unemployment Experiences: } \\
\text { Heterogeneity and Business Cycle Effects }\end{array}$ & 3 & 09/01 \\
\hline 371 & $\begin{array}{l}\text { S. C. Wolter } \\
\text { A. Zbinden }\end{array}$ & $\begin{array}{l}\text { Rates of Return to Education: The View of } \\
\text { Students in Switzerland }\end{array}$ & 5 & 09/01 \\
\hline 372 & $\begin{array}{l}\text { J. Konings } \\
\text { H. Lehmann }\end{array}$ & $\begin{array}{l}\text { Marshall and Labour Demand in Russia: Going } \\
\text { Back to Basics }\end{array}$ & 4 & 09/01 \\
\hline 373 & S. J. Trejo & $\begin{array}{l}\text { Does the Statutory Overtime Premium } \\
\text { Discourage Long Workweeks? }\end{array}$ & 1 & $10 / 01$ \\
\hline
\end{tabular}

